\title{
Using Defined Processes as a Context for Resilience Measures
}

\author{
Julia H. Allen \\ Pamela D. Curtis \\ Linda Parker Gates
}

December 2011

TECHNICAL NOTE

CMU/SEI-2011-TN-029

CERT $^{\circledR}$ Program

http://www.sei.cmu.edu

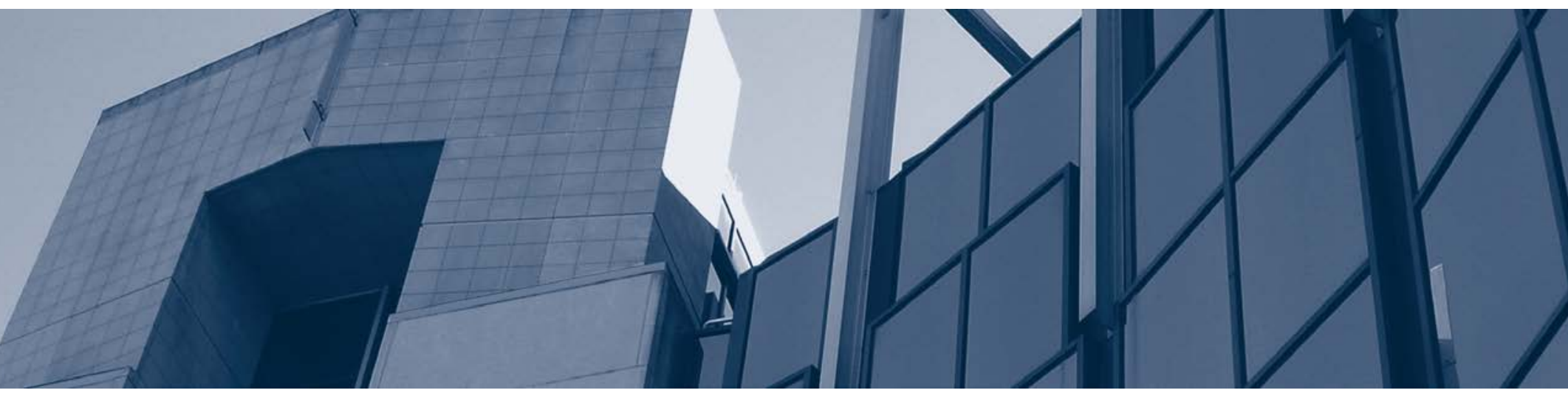


Copyright 2011 Carnegie Mellon University.

This material is based upon work funded and supported by the United States Department of Defense under Contract No. FA8721-05-C-0003 with Carnegie Mellon University for the operation of the Software Engineering Institute, a federally funded research and development center.

Any opinions, findings and conclusions or recommendations expressed in this material are those of the author(s) and do not necessarily reflect the views of the United States Department of Defense.

This report was prepared for the

SEI Administrative Agent

ESC/CAA

20 Schilling Circle, Bldg 1305, 3rd floor

Hanscom AFB, MA 01731-2125NO WARRANTY

THIS CARNEGIE MELLON UNIVERSITY AND SOFTWARE ENGINEERING INSTITUTE MATERIAL IS FURNISHED ON AN “AS-IS” BASIS. CARNEGIE MELLON UNIVERSITY MAKES NO WARRANTIES OF ANY KIND, EITHER EXPRESSED OR IMPLIED, AS TO ANY MATTER INCLUDING, BUT NOT LIMITED TO, WARRANTY OF FITNESS FOR PURPOSE OR MERCHANTABILITY, EXCLUSIVITY, OR RESULTS OBTAINED FROM USE OF THE MATERIAL. CARNEGIE MELLON UNIVERSITY DOES NOT MAKE ANY WARRANTY OF ANY KIND WITH RESPECT TO FREEDOM FROM PATENT, TRADEMARK, OR COPYRIGHT INFRINGEMENT.

This material has been approved for public release and unlimited distribution except as restricted below.

Internal use:* Permission to reproduce this material and to prepare derivative works from this material for internal use is granted, provided the copyright and "No Warranty" statements are included with all reproductions and derivative works.

External use:* This material may be reproduced in its entirety, without modification, and freely distributed in written or electronic form without requesting formal permission. Permission is required for any other external and/or commercial use. Requests for permission should be directed to the Software Engineering Institute at permission@sei.cmu.edu.

® CERT, CERT Resilience Management Model, and CERT-RMM are registered marks owned by Carnegie Mellon University.

* These restrictions do not apply to U.S. government entities. 


\section{Table of Contents}

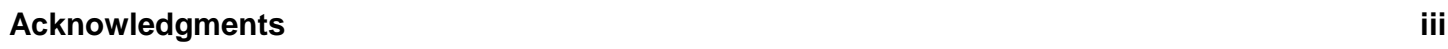

$\begin{array}{lc}\text { Abstract } & \mathbf{v}\end{array}$

1 Introduction $r$

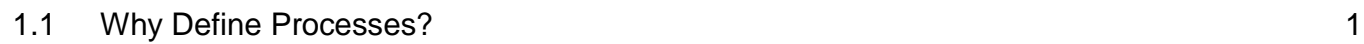

1.2 Why Use Defined Processes as a Basis for Selecting and Defining Measures?

2 Defining Processes and Procedures $\quad 3$

2.1 Process Definition Elements 3

2.2 Defining Processes 3

$\begin{array}{lll}2.3 & \text { Defining Procedures } & 4\end{array}$

$3 \quad$ Selecting Measures $\quad 5$

$\begin{array}{lll}3.1 & \text { Defining Measures }\end{array}$

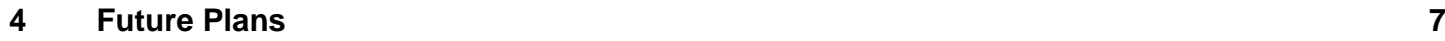

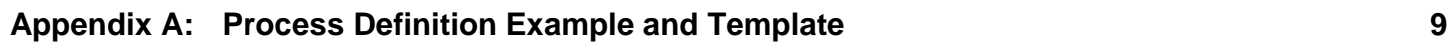

\begin{tabular}{lr} 
Appendix B: & Procedure Definition Example and Template \\
\hline
\end{tabular}

Appendix C: Information Asset Profile Example and Template 27

Appendix D: Alternative Process or Procedure Example and Template 35

Appendix E: $\quad$ Measure Definition Example and Template $\quad 41$

$\begin{array}{lr}\text { References } & 46\end{array}$ 
CMU/SEI-2011-TN-029 | ii 


\section{Acknowledgments}

The authors would like to thank the reviewers of this report who generously contributed their time, knowledge, and experience to provide comments that greatly enhanced the clarity and accuracy of the concepts presented. Reviewers are members of the CERT ${ }^{\circledR}$ Resilient Enterprise Management team, the CERT Enterprise and Workforce Development team, and the Software Engineering Institute's Software Engineering Process Management program:

- $\quad$ Richard Barbour

- James Cebula

- Lisa Marino

- Michael Rattigan

- Barbara Tyson

- David White

- Lisa Young

The authors would also like to thank the members of the CERT ${ }^{\circledR}$ Resilience Management Model (CERT ${ }^{\circledR}$ RMM) Users Group, who are using these materials and providing feedback as part of their organizational improvement projects. 
CMU/SEI-2011-TN-029 | iv 


\section{Abstract}

The CERT ${ }^{\circledR}$ Resilient Enterprise Management (REM) team is researching operational resilience and the organizational processes that support it. This technical note, which builds on two previous reports, describes how implementation-level processes can provide the necessary context for identifying and defining measures of operational resilience. The team's first report, Measuring Operational Resilience Using the CERT ${ }^{\circledR}$ Resilience Management Model (CMU/SEI-2010-TN-030), defined high-level objectives for an operational resilience management system, demonstrated how to derive meaningful measures from those objectives, and presented a template for defining resilience measures. The team's second report, Measures for Managing Operational Resilience (CMU/SEI-2011-TR-019), suggested strategic measures for managing operational resilience and provided candidate measures for the 26 process areas of the CERT ${ }^{\circledR}$ Resilience Management Model, Version $1.1\left(\right.$ CERT $^{\circledR}-\mathrm{RMM}^{\mathrm{B}}$.

While CERT-RMM defines the commonly used or best practices for operational resilience-what an organization should do-organization-specific processes must be defined at the implementation level to describe how to perform those practices. Organizations can then identify and define measures within the context of their specific processes and procedures. Organizations can use the measures to evaluate process performance and operational resilience and identify opportunities for improvement. This technical note provides examples and templates for defining processes and procedures and for defining related assets and measures. 
CMU/SEI-2011-TN-029 | vi 


\section{Introduction}

In January 2010, the CERT ${ }^{\circledR}$ Program initiated the resilience measurement and analysis research project. This technical note is the third in a series describing an approach for measuring operational resilience using the CERT $^{\circledR}$ Resilience Management Model (CERT ${ }^{\circledR}$-RMM) as the reference maturity model. Readers are encouraged to read Measuring Operational Resilience Using the CERT ${ }^{\circledR}$ Resilience Management Model [Allen 2010] and Measures for Managing Operational Resilience [Allen 2011], the first two reports in this series, for the background and foundation for this technical note.

\subsection{Why Define Processes?}

A process definition describes the activities and tasks necessary to perform work consistently. Defined processes allow for repeatability and prediction and also form a foundation for measurement and improvement of operational resilience. In fact, a key prerequisite for identifying appropriate process measures is a defined and well-understood process.

Process measures are integral to resilience improvement because they make it possible to predict the impact of proposed changes and assess their results. Process measures can also help demonstrate that investments in operational resilience have measurable business value. Having clear process improvement goals will determine the kinds of entities and attributes that must be measured.

There is a cost associated with defining processes and keeping process definitions up to date. It is not always possible or necessary to define every process an organization enacts. It is, however, necessary to define processes if an organization wishes to analyze, measure, or improve them. In fact, defined processes facilitate a number of organizational objectives:

- facilitating feedback and learning

- providing a basis for improvement

- $\quad$ simplifying the execution of routine tasks

- making work manageable and predictable (and thus more easily planned)

- ensuring consistent, high-quality implementation (which can assist with high-risk or externally regulated processes)

- reducing the need for reinvention

A maturity model such as CERT-RMM defines commonly used or best practices—what an organization should do. But maturity models are not measurable. Process definitions describe how an organization actually performs work and are specific to organizations, people, facilities, and operations. A well-understood, welldefined, implemented process is a prerequisite for measurement of operational resilience; a maturity model cannot satisfy this need.

CERT-RMM guides both assessment and improvement of operational resilience processes. Defining (and refining) a process in the context of a maturity model, coupled with measurement, is a powerful tool for improvement.

${ }^{\circledR} \quad$ CERT, CERT Resilience Management Model, and CERT-RMM are registered marks owned by Carnegie Mellon University. 


\subsection{Why Use Defined Processes as a Basis for Selecting and Defining Measures?}

Measurement supports transforming strategic direction, policy, and other forms of management decisions into action and evaluating the performance of such action. The right measures express:

- the extent to which objectives are being met

- how well requirements are being satisfied

- how well processes and controls are functioning

- the extent to which performance outcomes are being achieved

The CERT resilience measurement and analysis research project is focused on examining what should be measured to determine whether process performance objectives for operational resilience are being achieved and how performance should be measured. While measuring operational resilience may be most accurately done during or after times of stress and disruption, this is often too late to be beneficial. Typically, the organization is in too reactive a mode even to consider how to improve in anticipation of the next incident. Also, knowing how well the organization responded to previous attacks is not sufficient. The organization must be able to predict how it will perform in the future when the threat and risk environment changes.

An organization may gain more confidence and precision about its state of readiness by examining the fidelity and performance of the processes that contribute to its operational resilience- these are, at least, two important indicators that are not typically measured today. Such an examination requires defining and improving processes at the implementation level, as described in Section 1.1, and then identifying and defining measures within the context of these processes and their corresponding procedures. The intent is to collect, analyze, and report in-process measures as processes are being performed and use such measures to evaluate process performance, identify process improvements, and better understand the organization's capability to manage operational resilience. In addition, defined processes support and enable the consistent measurement of activities that may be outside the scope of evaluating process performance. For example, if an organization has a defined process for managing incidents, then it should have much more confidence in measures related to the number of incidents and their impact over time. If an organization instead performs ad hoc incident management, the number of incidents counted could be suspect. Defined processes produce related measures that are more collectible, consistent, reliable, and accurate.

To make informed decisions, affect behavior, and manage any activity, including operational resilience, organizational leaders need consistent, timely, and accurate measurements. A quotation often attributed to Deming states, “If you can’t describe what you are doing as a process, you don’t know what you're doing."1 And if you don't know what you are doing, measurement and analysis will not help. Attempting to measure operational resilience without the foundation of a defined process is not very meaningful.

In the following sections, we describe an approach for defining processes and their corresponding procedures, and then selecting and defining measures based on those processes.

"W. Edwards Deming." BrainyQuote.com. Xplore Inc, 2010. Accessed September 22, 2011. http://www.brainyquote.com/quotes/quotes/w/wedwardsd133510.html 


\section{Defining Processes and Procedures ${ }^{2}$}

\subsection{Process Definition Elements}

A process is a systematic series of actions directed to some end. ${ }^{3}$ The building blocks of process definitions are activities, people, and work products (also known as activities, agents, and artifacts). A process definition describes the work product or result of the process, the activities that produce that result and their sequence, and the roles that individuals or teams play in achieving the outcome-in essence, what happens, who does it, and what is accomplished. There are several other elements that make up a thorough definition of a process, as shown in Table 1.

Table 1: Key Process Definition Elements

\begin{tabular}{|l|l|}
\hline Process Definition Element & Description \\
\hline Purpose & The reason for performing the process \\
\hline Scope & The extent or range of the process \\
\hline Activities & The specific actions that are taken \\
\hline Process Flow Diagram & A graphical depiction of the layout of the process activities \\
\hline Inputs & Work products necessary for executing the process \\
\hline Outputs & Work products generated by the process \\
\hline Entry Criteria & Conditions that must be met for the process to begin \\
\hline Exit Criteria & Conditions that must be met for the process to be considered complete \\
\hline Roles & The functions people serve in the process \\
\hline Requirements & $\begin{array}{l}\text { Any demands placed on the process by the organization or type of work, and any resilience } \\
\text { requirements that apply to the people, information assets, technology assets, and facilities } \\
\text { involved in the process }\end{array}$ \\
\hline Controls & Policies, standards, or methods that limit the process or help satisfy process requirements \\
\hline Mechanisms & Tools or systems used to assist the process \\
\hline Verification & Activities to verify the consistent use of the process \\
\hline Measures & $\begin{array}{l}\text { Activities to assess process performance and to collect and analyze information needed to } \\
\text { evaluate the extent to which management objectives are being met }\end{array}$ \\
\hline
\end{tabular}

\subsection{Defining Processes}

There are many tools and techniques available for defining processes (see, for example, Humphrey [1989] and SPC [1996]). The Total Quality Management (TQM) literature, for example, provides many respected techniques, templates, and tools (see, for example, Brassard [2010]).

A quick and effective approach to documenting a process is to prepare an initial draft and then conduct an interview with a knowledgeable process user to verify and populate the draft. The draft is an assumptive view of how a process works, presented as a rough model. Although the draft may not accurately represent the way

2 The process definition information in this section is based on material presented in the Software Engineering Institute's Mastering Process Improvement training course (http://www.sei.cmu.edu/training/p15b.cfm).

3 "process" Dictionary.com. Accessed September 22, 2011. http://dictionary.reference.com/browse/process

$4 \quad$ Appendix $B$ provides a template for documenting resilience requirements for assets used in operational resilience processes. 
the process actually works, it will help scope and jumpstart the interview. It allows quick alignment and shared understanding between the interviewer and the interviewee, who can then validate the high-level definition and provide details on the specific activities.

The set of key questions shown in Table 2 can be used to conduct a process definition interview.

Table 2: Key Questions for Defining a Process

\begin{tabular}{|c|c|}
\hline Key Question & Process Definition Element \\
\hline Why is the process performed? & Purpose \\
\hline What is the scope of the process? & Scope \\
\hline What work product(s) or results are generated by the process? & Outputs \\
\hline What conditions must be met for the process to begin and end? & Entry and Exit Criteria \\
\hline What work product(s) are required to initiate the process? & Inputs \\
\hline What activities are performed and in what sequence? & Activities \\
\hline Who performs the activities of the process? & Roles \\
\hline What organizational, resilience, or other requirements apply to the process? & Requirements \\
\hline What controls are used to satisfy the requirements? & Controls \\
\hline What mechanisms are used to aid in the implementation of the process? & Mechanisms \\
\hline What activities are performed to verify the consistent use of the process? & Verification \\
\hline How is performance of the process assessed? & Measures \\
\hline
\end{tabular}

A process definition, usually a combination of graphics and text, facilitates analysis and execution of the process. As a model of a process, the process definition is not exhaustive, but it does define the activities, conditions, and other required context within which measurement is performed.

Appendix A provides an example process definition, "Data Handling," and a process definition template. The template contains all the necessary elements for defining a process and using it as the context for measurement and improvement. Some of the elements will not be needed for certain processes. For example, a process might not have any externally imposed requirements. However, all elements in the template should be considered before determining that they are not needed.

\subsection{Defining Procedures}

As stated in Section 1.1, a process describes how an organization actually performs work and is specific to organizations, people, facilities, and operations. But a process is not always fully implementable if it is not specified at the level of detail required to perform the process. In fact, it is often desirable to have a generalpurpose process that can be applied to a broad range of activities or work products. A procedure, then, provides detailed instructions, often at the level of a particular activity, work product, or role, when more specificity is required to perform (and measure) the process. Appendix A defines an example data handling process that can be applied to a range of data types, and Appendix B defines an example procedure for a specific type of data.

Procedure definitions comprise the same kinds of elements that describe a process. Appendix B provides a procedure definition example and a procedure definition template. As with the process definition template, the procedure definition template contains all the necessary elements for defining a procedure as the context for measurement and improvement. Some of the elements will not be needed for certain procedures, but organizations should consider all elements in the template. 


\section{Selecting Measures}

As described by Allen [2010], before an organization can select a measure, it must determine key information and context, including

- the resilience objective that the measure is intended to address. The objective should be connected to organizational strategic goals and critical success factors, organizational resilience goals, service resilience goals, and/or asset resilience goals. For example, a resilience objective might be "The Operational Resilience Management System (ORMS) manages (identifies, analyzes, mitigates) operational risks to high-value assets that could adversely affect the operation and delivery of high-value services," and, more specifically, "Protect and sustain designated data."

- the question(s) that the measure is intended to answer. For example, a question might be "How many incidents occurred during the last quarter?" or, more specifically, "How many breaches of confidentiality and privacy occurred as a result of unauthorized access of designated data in the last month?” The question should relate to the objective and to the defined processes that support the objective.

In this technical note, we add the process dimension to the set of key information by describing the related processes and procedures within which the measure is collected, analyzed, and reported.

The thought process and steps for selecting the 10 measures that are included in the Data Handling process example in Appendix A are described below. Based on our experience to date, we believe these steps (or some variation thereof) can be used to identify measures for any process. (The measure IDs are from the Measures table in the example.)

1. For the process overall or for each process activity, are there key stakeholder requirements that need to be satisfied? How would satisfaction be demonstrated? For example:

a. A report reflecting the results of a survey or assessment must be received within 45 calendar days. One measure is "elapsed time between creation or receipt of data and delivery of data final report (mean, median)” (measure DH-M1).

b. All designated data in digital form can only be accessed by those with a need to know. One measure is "number of breaches of confidentiality and privacy of designated data traced to violations of access control policies” (measure DH-M2; refer also to Appendix E for a complete definition of this measure).

c. All data handling requirements are met. One measure is "number of violations of Data Handling requirements” (measure DH-M3).

2. For each process verification activity, what needs to be demonstrated to verify that the process was performed as defined and as expected? For example:

a. Designated data that resides on access-controlled servers can be recovered and restored in accordance with service level agreements. One measure is "elapsed time (from initial request) to recover data from backups (mean, median)” (measure DH-M9).

3. Are there CERT-RMM v1.1 measures (as updated by Allen [2011]) that aid in determining the extent to which this process has been implemented? And the extent to which this process is effective? For example: 
a. difference in planned versus actual schedule (number of days) to perform the Data Handling process (measure DH-M4)

b. difference in planned versus actual cost to perform the Data Handling process (measure DH-M5)

4. Evaluate what would need to be measured to determine if each process activity was performed as expected. For example:

a. For the process activity "Create or receive the data," one measure is "number of instances of data received or created” (measure DH-M4).

b. For the process activity "Return or destroy the data," one measure is "number of instances of data returned or destroyed” (measure DH-M7).

c. For each data engagement, the two measures above would need to be compared and reconciled to ensure that all data received or created has been returned or destroyed, or that the designated party has explicitly approved retention of certain data (measure DH-M8).

Our intent is for each of these steps to demonstrate the value of having a defined process to use as the context for selecting measures. Without some defined process as the context, it is difficult to envision how meaningful measures would be selected and analyzed, how data to support such measures could be consistently collected, and how decisions and behavior would be informed by measurement reports. That said, in the absence of a defined process, resilience objectives and questions could be used as a starting point.

\subsection{Defining Measures}

Allen [2010] describes how using a measurement template helps thoroughly define a measure, including such information as who will use the measure, what is being measured, what data needs to be collected and where it is stored, how the data is collected, and how the measure is visually presented. Defining a measure using a template provides repeatability in collecting, analyzing, and reporting it. Appendix E shows an example of how a measure can be fully defined using the measurement template that was originally published in Allen [2010], updated to include traceability to related processes and procedures. The example uses measure DH-M2 from the Data Handling process. 


\section{Future Plans}

This research project will continue through FY12 (October 2011 through September 2012). Future plans include the following:

- Assist in developing new process and procedure definitions as informed by selected customers and the CERT-RMM Users Group. ${ }^{5}$

- Pilot and improve selected implementation and effectiveness measures within the context of defined processes. Effectiveness measures, in particular, will be analyzed to determine the extent to which an improved process measurably contributes to improved operational resilience.

- $\quad$ Reflect new and updated measures in CERT-RMM v2.0.

The team will also develop additional measures templates for key measures (refer to Allen [2011] and Appendix E).

5 For more information about the CERT-RMM Users Group, see http://www.sei.cmu.edu/training/P92.cfm. 


\section{Appendix A: Process Definition Example and Template}

\section{EXAMPLE}

This fictitious example is a process for handling data submitted to or generated by ABC Organization.

\section{Data Handling Process Definition}

\section{Process Purpose}

The purpose of the Data Handling process is to protect and sustain designated data in accordance with ABC Organization requirements, compliance obligations, and policies and standard practices.

\section{Scope}

This process applies to designated data handled by ABC Organization staff.

\section{Acronyms and Definitions}

CERT $^{\circledR}$-RMM $\quad$ CERT $^{\circledR}$ Resilience Management Model

\section{Outputs}

- $\quad$ Resilient (protected and sustained) data as defined by CERT-RMM

\section{Entry Criteria}

- Data is created ${ }^{6}$ or received.

\section{Inputs}

- Designated data that ABC Organization staff collect and develop:

- $\quad$ survey data

- diagnostic data

- performance data

- Data that external parties provide and ABC Organization staff retain (documents, reports, spreadsheets, etc.)

\section{Requirements}

- Refer to the data set's information asset profile [see Appendix C for an example].

6 Data creation begins the moment data is recorded or shared in physical form or digital form. 


\section{Controls}

Policies

- ABC Organization Intellectual Property Policy

Procedures

- Survey Data Handling procedure

- Diagnostic Data Handling procedure

- Performance Data Handling procedure

- External Party Data Handling procedure

Standards

- $\quad$ ABC Organization Standard Practice for Dealing with the Media

- ABC Organization Standard Practice for Disclosure of Unclassified Information

- ABC Organization Controlled Information Management System Standard of Conduct and Procedures

Methods and Technologies

- ABC Organization Controlled Information Management System

- encrypted desktop and laptop hard drives

- encrypted WinZip files (for attachment to emails)

- access-controlled Microsoft SharePoint sites

- locked file cabinets

\section{Mechanisms}

Templates

- Survey report template

- Diagnostic report template

- Performance report template

Tools

- Microsoft SharePoint

- Disk encryption and decryption software

- WinZip-compatible encryption and decryption software

\section{Roles}

The following roles apply to the handling of designated data types:

\begin{tabular}{|l|l|l|}
\hline Role & Description & Responsibility \\
\hline $\begin{array}{l}\text { ABC staff (exact role } \\
\text { varies) }\end{array}$ & $\begin{array}{l}\text { Staff member who participates in the receipt of data, } \\
\text { has access to it, and handles it }\end{array}$ & In most cases, acts as a custodian of the data \\
\hline ABC team/project lead & $\begin{array}{l}\text { Leader of the team or project that conducts activities } \\
\text { that handle data }\end{array}$ & $\begin{array}{l}\text { Manages the conduct, reporting, and measurement } \\
\text { associated with data handling activities }\end{array}$ \\
\hline ABC editor & Technical editor & Edits reports containing the data \\
\hline ABC IT administrator & $\begin{array}{l}\text { IT staff member who backs up and restores data } \\
\text { residing on SharePoint servers }\end{array}$ & $\begin{array}{l}\text { Performs regular backups and tests ability to } \\
\text { restore from backups; ensures that data that } \\
\text { resides on SharePoint servers is encrypted }\end{array}$ \\
\hline
\end{tabular}




\section{Activities}

The following activities apply to the handling of designated data types unless otherwise noted in the applicable procedure for that data type:

\begin{tabular}{|c|c|c|c|c|}
\hline $\begin{array}{l}\text { Activity } \\
\text { No. }\end{array}$ & Data Handling Activities & Description & $\begin{array}{l}\text { Applicable } \\
\text { Measures }^{\text {a }}\end{array}$ & Role \\
\hline 1.0 & Create or receive the data & Data is received or created in physical or digital form. & $\begin{array}{l}\text { M1, M3, M4, } \\
\text { M6, M8 }\end{array}$ & ABC staff \\
\hline 2.0 & Transport the data & $\begin{array}{l}\text { Physical data is securely transported from one location } \\
\text { to another, typically from the external party or other } \\
A B C \text { site to the designated } A B C \text { site. }\end{array}$ & M2, M3 & ABC staff \\
\hline 3.0 & Store the data & $\begin{array}{l}\text { Physical data is secured in safes or locked file } \\
\text { cabinets. Digital data is encrypted on desktops and } \\
\text { laptops. Digital data does not reside on mobile devices } \\
\text { or removable storage devices. Digital data is stored on } \\
\text { access-controlled SharePoint sites. }\end{array}$ & M2, M3 & $\begin{array}{l}\text { ABC team lead } \\
A B C \text { staff }\end{array}$ \\
\hline 4.0 & $\begin{array}{l}\text { Share and access the data } \\
\text { (internal to } A B C \\
\text { Organization) }\end{array}$ & $\begin{array}{l}\text { Digital data is accessed from access-controlled } \\
\text { SharePoint sites. Digital data is encrypted and } \\
\text { exchanged via email. }\end{array}$ & M2, M3 & $\begin{array}{l}\text { ABC team lead } \\
A B C \text { staff } \\
A B C \text { editor }\end{array}$ \\
\hline 5.0 & $\begin{array}{l}\text { Deliver the data (to an } \\
\text { external party) }\end{array}$ & $\begin{array}{l}\text { Digital data (e.g., reports, presentations) is encrypted } \\
\text { and exchanged with an external party via email. }\end{array}$ & $\mathrm{M} 1, \mathrm{M} 2, \mathrm{M} 3$ & $\begin{array}{l}A B C \text { team lead } \\
A B C \text { staff }\end{array}$ \\
\hline 6.0 & Destroy or return the data & $\begin{array}{l}\text { Physical and digital data is destroyed or returned in } \\
\text { accordance with requirements. }\end{array}$ & $\begin{array}{l}\text { M2, M3, M4, } \\
\text { M7, M8 }\end{array}$ & $\begin{array}{l}A B C \text { team lead } \\
A B C \text { staff }\end{array}$ \\
\hline 7.0 & Back up the data & $\begin{array}{l}\text { Digital data is backed up by } A B C \text { IT in accordance with } \\
\text { the posted service level agreement. All backups are } \\
\text { encrypted. }\end{array}$ & & ABC IT administrator \\
\hline 8.0 & $\begin{array}{l}\text { Restore the data from } \\
\text { backups }\end{array}$ & $\begin{array}{l}\text { Upon } A B C \text { team lead request, data is restored to } \\
\text { access-controlled SharePoint sites as needed. The } \\
\text { ability to restore digital data from backups is regularly } \\
\text { tested in accordance with the posted service level } \\
\text { agreement. }\end{array}$ & M9, M10 & ABC IT administrator \\
\hline
\end{tabular}

${ }^{a}$ See Measures table.

\section{Verification}

Unless otherwise specified, the following verification activities are performed externally to (or independently of) the process: ${ }^{7}$

- Audits are conducted periodically to verify that data in physical form has been securely transported and stored in accordance with requirements.

- Audits are conducted periodically to verify that data in digital form has been securely stored and shared in accordance with requirements.

- Scripts are run against SharePoint sites periodically to verify that attempts to access data by unauthorized parties fail.

- If data is restored, it is successfully restored in the requested version to the correct access-controlled SharePoint site.

- The ability to restore data from backups is regularly tested.

- The ABC team lead verifies that data is returned or destroyed in accordance with requirements.

$7 \quad$ Verification roles are not identified due to verification activities being performed externally to the process. If such activities are performed internally to the process, roles should be identified here. 


\section{Measures}

The following candidate ${ }^{8}$ measures apply to the handling of most data types. Variations or new measures that apply to a specific type of data are defined in the applicable procedure for that data type.

\begin{tabular}{|c|c|c|c|c|c|c|}
\hline ID & Measure & Type of Information & Measure Type & Base or Derived & Activities & Applicable SG.SP \\
\hline DH-M1 & $\begin{array}{l}\text { Elapsed time between creation or receipt of data and } \\
\text { delivery of data final report (mean, median) }\end{array}$ & Final report & Implementation & $\begin{array}{l}\text { Base of type } \\
\text { schedule }\end{array}$ & $1.0,5.0$ & $\begin{array}{l}\text { GG2.GP2 } \\
\text { GG2.GP8 }\end{array}$ \\
\hline DH-M2 & $\begin{array}{l}\text { Number of violations of access control requirements or } \\
\text { policies for data } \\
\text {-As a result, number of successful intrusions into } \\
\text { technology assets (digital data) or facility assets } \\
\text { (physical data) where data are stored, processed, and } \\
\text { transmitted } \\
\text {-As a result, number of instances of data being } \\
\text { accessed in an unauthorized manner } \\
\text {-As a result, number of incidents declared } \\
\text {-As a result, number of breaches of confidentiality and } \\
\text { privacy of data } \\
\text {-As a result, number of violations of requirements for } \\
\text { data }\end{array}$ & $\begin{array}{l}\text { Data intrusions } \\
\text { Data violations }\end{array}$ & $\begin{array}{l}\text { Implementation; } \\
\text { possibly } \\
\text { Effectiveness }\end{array}$ & Base of type count & $\begin{array}{l}\text { Physical data: } 2.0 \text {, } \\
3.0,6.0 \\
\text { Digital data: } \\
3.0-6.0\end{array}$ & $\begin{array}{l}\text { KIM:SG4.SP2 } \\
\text { KIM:SG5.SP1 } \\
\text { GG2.GP8 }\end{array}$ \\
\hline DH-M3 & Number of violations of data handling requirements & Requirements & Implementation & Base of type count & $1.0-6.0$ & KIM:SG4, SG5, SG6 \\
\hline DH-M4 & $\begin{array}{l}\text { Difference in planned versus actual schedule (number of } \\
\text { days) to perform the data handling process }{ }^{a}\end{array}$ & \begin{tabular}{|l} 
Plan \\
Procedure activities
\end{tabular} & $\begin{array}{l}\text { Implementation; } \\
\text { possibly } \\
\text { Effectiveness }\end{array}$ & Derived & $\begin{array}{l}\text { Planned: project } \\
\text { work plan } \\
\text { Actual: } 1.0,6.0\end{array}$ & $\begin{array}{l}\text { GG2.GP2 } \\
\text { GG2.GP8 }\end{array}$ \\
\hline
\end{tabular}

a The base measures from which this derived measure is calculated are the number of days between the planned process start date and the planned process end date compared with the number of days between the actual process start date and the actual process end date (see also DH-M8).

${ }^{b}$ The project work plan is developed outside of this process definition. It describes the activities, schedule, and costs for the engagement that results in the data handled by this process and its supporting procedures.

8 Measurement can be time consuming and expensive. Organizations should select those measures that are most meaningful to inform decisions and affect behaviors related to improving process performance and meeting management objectives. 


\section{Measures (continued) ${ }^{9}$}

\begin{tabular}{|c|c|c|c|c|c|c|}
\hline ID & Measure & Type of Information & Measure Type & Base or Derived & Activities & Applicable SG.SP \\
\hline DH-M5 & $\begin{array}{l}\text { Difference in planned versus actual cost to perform the } \\
\text { data handling process }{ }^{c}\end{array}$ & $\begin{array}{l}\text { Plan } \\
\text { Resources }\end{array}$ & $\begin{array}{l}\text { Implementation; } \\
\text { possibly } \\
\text { Effectiveness }\end{array}$ & Derived & $\begin{array}{l}\text { Planned: project } \\
\text { work plan } \\
\text { Actual: monthly } \\
\text { financial reports }\end{array}$ & $\begin{array}{l}\text { GG2.GP2 } \\
\text { GG2.GP8 }\end{array}$ \\
\hline DH-M6 & Number of instances of data received or created & Data receipt & Implementation & Base of type count & 1.0 & $\begin{array}{l}\text { ADM:SG1.SP1 } \\
\text { ADM:SG3.SP2 } \\
\text { GG2.GP8 }\end{array}$ \\
\hline DH-M7 & Number of instances of data returned or destroyed & $\begin{array}{l}\text { Data return or } \\
\text { destruction }\end{array}$ & Implementation & Base of type count & 6.0 & $\begin{array}{l}\text { ADM:SG1.SP1 } \\
\text { ADM:SG3.SP2 } \\
\text { GG2.GP8 }\end{array}$ \\
\hline DH-M8 & $\begin{array}{l}\text { Elapsed time between creation or receipt of data and } \\
\text { the return of the data to its owner and/or its destruction } \\
\text { in any } A B C \text { facility or on any } A B C \text { technology asset } \\
\text { (mean, median) }\end{array}$ & $\begin{array}{l}\text { Data return or } \\
\text { destruction }\end{array}$ & Implementation & $\begin{array}{l}\text { Base of type } \\
\text { schedule }\end{array}$ & $1.0,6.0$ & $\begin{array}{l}\text { ADM:SG1.SP1 } \\
\text { ADM:SG3.SP2 } \\
\text { GG2.GP8 }\end{array}$ \\
\hline DH-M9 & $\begin{array}{l}\text { Elapsed time (from initial request) to recover data from } \\
\text { backups (mean, median) }\end{array}$ & Data sustainment & Implementation & $\begin{array}{l}\text { Base of type } \\
\text { schedule }\end{array}$ & 8.0 & $\begin{array}{l}\text { KIM:SG6.SP1 } \\
\text { GG2.GP8 }\end{array}$ \\
\hline DH-M10 & $\begin{array}{l}\text { Percentage of data recovered that does not match the } \\
\text { most current version of data backed up (should be } 0 \% \text { ) }\end{array}$ & Data sustainment & Implementation & Derived & 8.0 & $\begin{array}{l}\text { KIM:SG6.SP1 } \\
\text { GG2.GP8 }\end{array}$ \\
\hline
\end{tabular}

${ }^{\mathrm{c}}$ The base measures from which this derived measure is calculated are the estimated cost of effort, travel, and other related expenses compared with the actual cost as of the process end date. 


\section{Exit Criteria}

- Data has been protected and sustained in accordance with requirements.

- Data has been returned or destroyed in accordance with requirements.

Referenced Sources

[Allen 2010] Allen, Julia, \& Davis, Noopur. Measuring Operational Resilience Using the CERT ${ }^{\circledR}$ Resilience Management Model (CMU/SEI-2010-TN-030). Software Engineering Institute, Carnegie Mellon University, September 2010.

http://www.sei.cmu.edu/library/abstracts/reports/10tn030.cfm 


\section{TEMPLATE}

\section{[Name] Process Definition}

\section{Purpose}

The purpose of the [process name] process is...

Scope

This process applies to...

Acronyms and Definitions

ACR1 Definition

ACR2 Definition

\section{Outputs}

[List the expected work product(s) produced from the activities of the process.]

•

\section{Context Diagram}

[If desired, show the context within which process activities occur.]

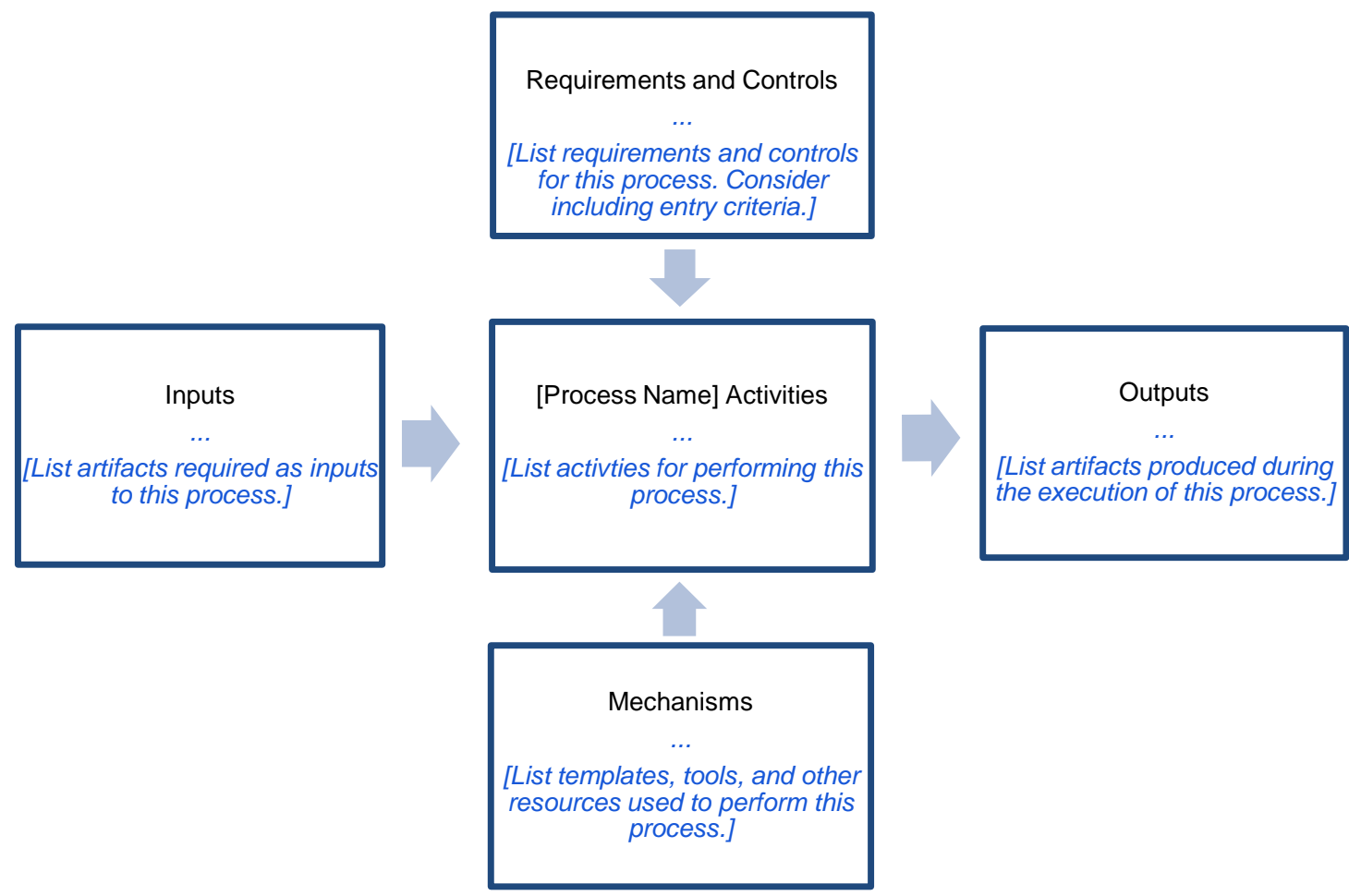




\section{Entry Criteria}

[List the conditions that must be met for the process to begin.]

$\bullet$

Inputs

[List the expected inputs to the process.]

\section{Requirements}

[List the requirements relevant to the process, including externally imposed requirements such as standards, laws, and regulations, or reference a separate source, such as an asset profile.]

\section{Controls}

[List the controls that are used to satisfy the requirements for the process in the following categories.]

-

Policies

[List the relevant policies for the process.]

Procedures

[List the procedures referenced in this process or that derive from the process.]

Standards

[List the relevant standards for the process.]

Methods and Technologies

[List the relevant methods and technologies for the process.]

Training

[List the training required for the process.]

\section{Mechanisms}

[List the mechanisms used to aid in the implementation of the process.]

\section{Guidelines}

[List the relevant guidelines for the process.]

Templates

[List the templates used in the process.]

Checklists

[List the checklists referenced in the process.]

Tools

[List the tools used to implement the process.] 
Process Flow Diagram

[If desired, show the sequence of activities that compose the process.]

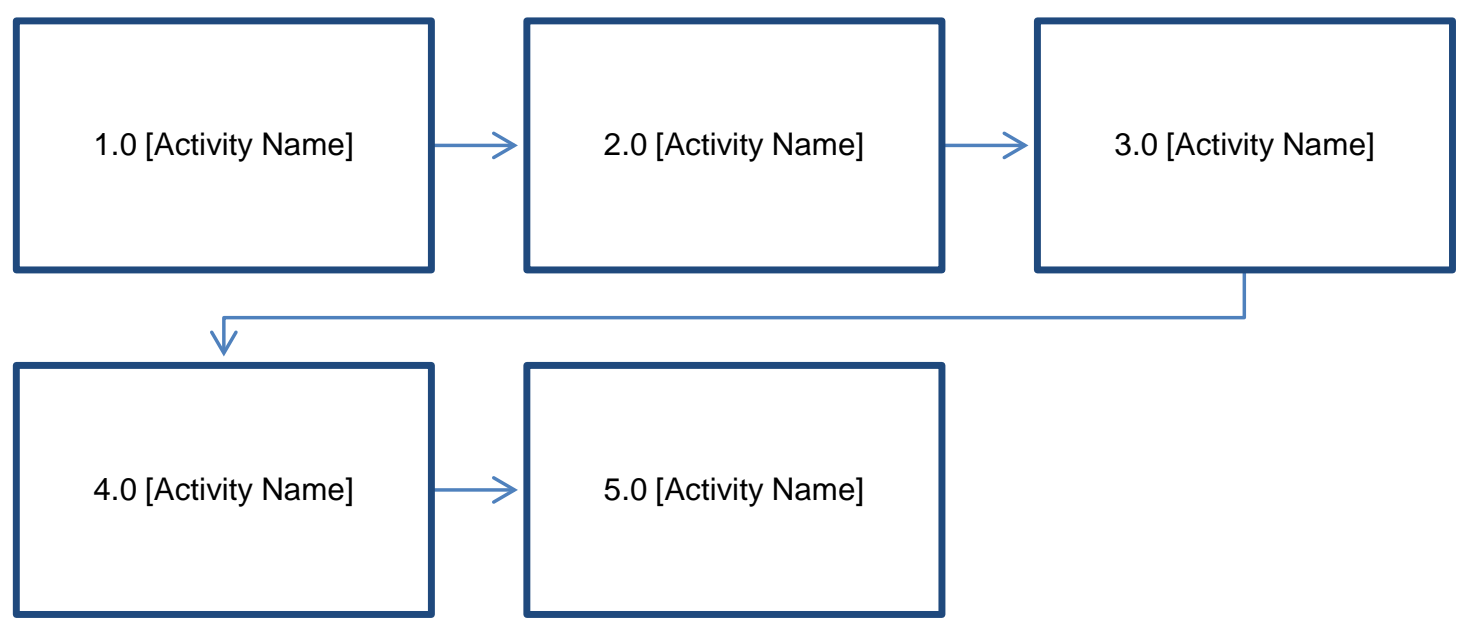

\section{Roles}

[Describe the roles that perform the process.]

\begin{tabular}{|l|l|l|}
\hline Role & Description & Responsibility \\
\hline [role name $]$ & [role description] & [responsibilities of the role] \\
\hline & & \\
\hline
\end{tabular}

\section{Swim Lane Diagram}

[If desired, show the relationship of roles responsible for performing process activities.]

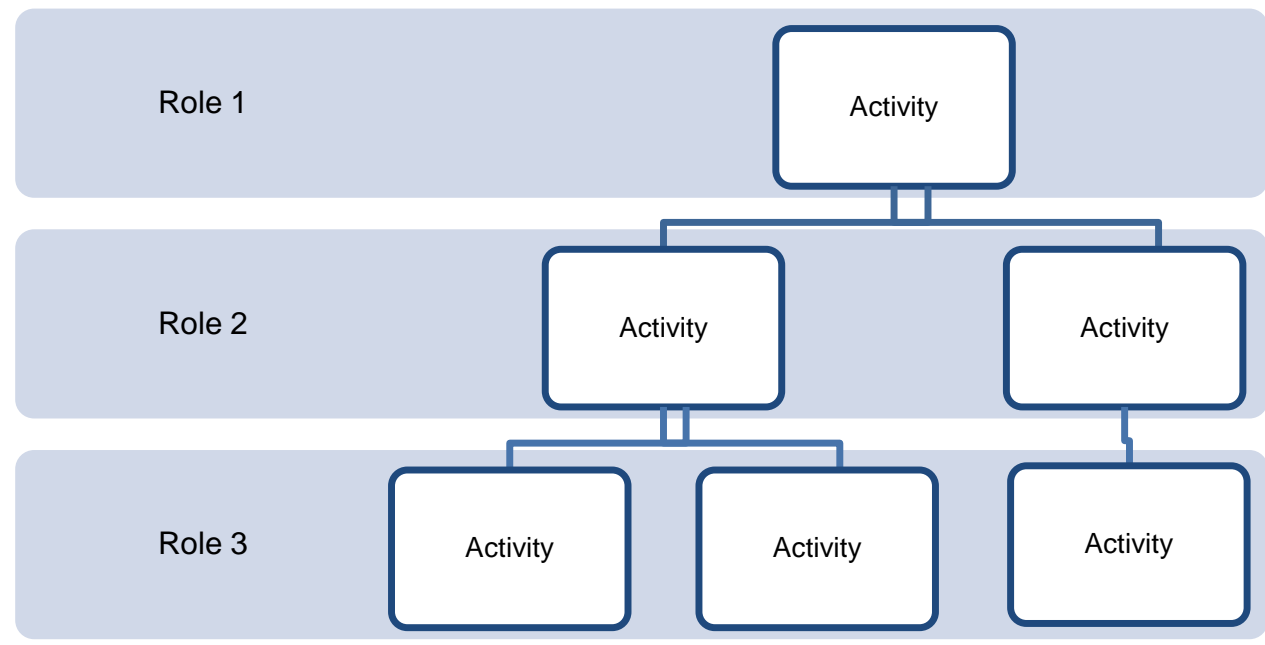




\section{Activities}

[Describe the activities that compose the process.]

\begin{tabular}{|c|c|c|c|c|}
\hline Activity No. & $\begin{array}{l}\text { [Process Name] } \\
\text { Activities }\end{array}$ & Description & $\begin{array}{l}\text { Applicable } \\
\text { Measures }^{\text {a }}\end{array}$ & Role \\
\hline $\begin{array}{l}\text { [sequential } \\
\text { number] }\end{array}$ & [activity name] & [activity description] & [measure ID] & $\begin{array}{l}\text { [role performing } \\
\text { the activity] }\end{array}$ \\
\hline
\end{tabular}

${ }^{\text {a }}$ See Measures table.

\section{Verification}

[Describe the verification activities that are necessary to confirm that the activities of the process have been adequately performed.]

The following verification activities are performed external to (or independent of) the process:

-

Measures $^{10}$

[Describe the measures used to support management information needs for the process.]

\begin{tabular}{|l|l|l|l|l|l|l|}
\hline ID & Measure & $\begin{array}{l}\text { Type of } \\
\text { Information }\end{array}$ & $\begin{array}{l}\text { Measure } \\
\text { Type }\end{array}$ & $\begin{array}{l}\text { Base or } \\
\text { Derived }\end{array}$ & Activities & $\begin{array}{l}\text { Applicable } \\
\text { SG.SP }\end{array}$ \\
\hline & & & & & & \\
\hline
\end{tabular}

[ID: A unique, sequential identifier assigned to each measure.]

[Measure: Measure description.]

[Type of Information: A category that can be used for affinity grouping of related measures. These can be work products (such as asset inventory and asset controls) or activities (such as change management and obligation satisfaction).]

[Measure Type: Implementation, effectiveness, or process performance.]

[Base or Derived: A base measure is a directly observable attribute of an asset, service, or resilience process; a derived measure is a mathematical function of two or more base and/or derived measures.]

[Activities: Assigned numbers of the activities in which the measure is collected.] [Applicable SG.SP: Related specific goal and specific practice in CERT-RMM.]

[For further definition of each column in the measures table, see Chapter 3 in Allen [2011].]

\section{Exit Criteria}

[List the conditions that must be satisfied for the process to be considered complete.]

\section{$\bullet$}

\section{Referenced Sources}

[List additional sources that are referenced in the process.]

10 Further details of how each measure is collected, analyzed, and reported are documented in Allen [2010]. 


\section{Appendix B: Procedure Definition Example and Template}

\section{EXAMPLE}

This fictitious example is a procedure for handling survey data submitted to ABC Organization by an external party. It is subordinate to the Data Handling process shown in Appendix A.

\section{Survey Data Handling Procedure Definition}

\section{Procedure Purpose}

The purpose of the Survey Data Handling procedure is to protect and sustain designated survey data in accordance with external party requirements and ABC Organization polices and standard practices.

\section{Scope}

This procedure applies to all designated survey data handled by the ABC Organization Survey Team.

Acronyms and Definitions

CERT-RMM

CERT Resilience Management Model

EP External party staff member

AST

ABC Organization Survey Team

\section{Outputs}

Resilient (protected and sustained) survey data

\section{Entry Criteria}

Survey data is created or received. ${ }^{11}$

Inputs

Survey data from external parties

\section{References}

Processes

Data Handling Process

Requirements

Refer to Survey Data Information Asset Profile [see Appendix C].

11 Data creation begins the moment survey data is recorded or shared in physical form or digital form. 
Roles

The following roles apply to the handling of all survey data:

\begin{tabular}{|l|l|l|l|}
\hline Role & $\begin{array}{l}\text { No. of } \\
\text { People }\end{array}$ & Description & Responsibility \\
\hline AST & $1-4$ & $\begin{array}{l}\text { ABC staff member who participates in one or } \\
\text { more surveys. Includes the survey team lead } \\
\text { and co-lead. }\end{array}$ & Acts as custodian of survey data \\
\hline $\begin{array}{l}\text { AST lead and co- } \\
\text { lead }\end{array}$ & $1-2$ & $\begin{array}{l}\text { Leader and co-leader of the team that } \\
\text { conducts a specific survey }\end{array}$ & $\begin{array}{l}\text { Manage survey program (schedules, budget, } \\
\text { tasking, etc.); manage the conduct, data } \\
\text { collection, reporting, and measurement } \\
\text { associated with a specific survey }\end{array}$ \\
\hline EP & $1-4$ & $\begin{array}{l}\text { Staff member from an external party } \\
\text { organization }\end{array}$ & $\begin{array}{l}\text { Owner of survey data; participates in } \\
\text { surveys; develops, presents, and provides } \\
\text { survey data }\end{array}$ \\
\hline ABC editor & 1 & Technical editor & $\begin{array}{l}\text { Edits the final survey report } \\
\text { ABC IT } \\
\text { administrator }\end{array}$ \\
\hline
\end{tabular}

\section{Activities}

The activities for handling survey data are described in the table below. Activities are as described in the Data Handling Process Definition. Unless otherwise indicated, AST members execute all activities.

\begin{tabular}{|l|l|}
\hline Activity & Description \\
\hline 1.0 Create or receive the data & $\begin{array}{l}\text { Survey data is obtained during survey meetings, via survey-related email, and via } \\
\text { postings to access-controlled SharePoint sites. }\end{array}$ \\
\hline 2.0 Transport the data & $\begin{array}{l}\text { Survey data that is provided in physical form during a survey meeting is securely } \\
\text { transported from the survey location to an AST member's office. }\end{array}$ \\
\hline 3.0 Store the data & $\begin{array}{l}\text { Survey data in digital form is stored on access-controlled SharePoint sites. Survey } \\
\text { data in physical form is stored in a locked desk or file cabinet after the completion of } \\
\text { the survey meeting where the data was provided. }\end{array}$ \\
\hline $\begin{array}{l}\text { 4.0 Share and access the data (internal to } \\
\text { the ABC Organization) }\end{array}$ & $\begin{array}{l}\text { Survey digital data is accessed from access-controlled SharePoint sites. } \\
\text { Survey data (in digital and physical form) can be accessed only by designated EP staff } \\
\text { (external SharePoint site) and AST members (external and internal SharePoint site). }\end{array}$ \\
\hline 5.0 Deliver the data (to the EP) & $\begin{array}{l}\text { Final encrypted data (such as reports and presentations), prepared by an ABC editor, } \\
\text { are sent to the EP via email. }\end{array}$ \\
\hline 6.0 Destroy or return the data & $\begin{array}{l}\text { Survey data in physical form is returned within 30 days of the end of the survey } \\
\text { project. } \\
\text { Survey data in digital form is destroyed within } 30 \text { days of the end of the survey project. } \\
\text { Destruction is confirmed with the EP. }\end{array}$ \\
\hline 7.0 Back up the data & $\begin{array}{l}\text { ABC IT administrators regularly back up SharePoint servers where survey data in } \\
\text { digital form resides. }\end{array}$ \\
\hline $\begin{array}{l}\text { Upon AST lead or co-lead request, data is restored to access-controlled SharePoint } \\
\text { sites as needed. ABC IT administrators regularly test the ability to restore data from } \\
\text { backups. }\end{array}$ \\
\hline
\end{tabular}




\section{Verification}

The verification activities for this procedure include the following:

- Audits are conducted periodically to verify that survey data in physical form has been securely transported and stored in accordance with requirements.

- Audits are conducted periodically to verify that survey data in digital form has been securely stored and shared in accordance with requirements.

- Scripts are run against SharePoint sites periodically to verify that attempts to access survey data by unauthorized parties fail.

- If survey data is restored, it is successfully restored in the requested version to the correct access-controlled SharePoint site.

- The ability to restore survey data from backups is periodically tested in accordance with ABC Organization service level agreements.

- The ABC team lead verifies that survey data is returned or destroyed in accordance with EP requirements. 


\section{Measures}

The following measures from the Data Handling Process apply to this procedure. The ID field shows the process measure ID and assigns a new procedure measure ID, for traceability.

\begin{tabular}{|c|c|c|c|c|c|c|}
\hline ID & Measure & $\begin{array}{l}\text { Type of } \\
\text { Information }\end{array}$ & Measure Type & Base or Derived & Activities & Applicable SG.SP \\
\hline $\begin{array}{l}\mathrm{DH}-\mathrm{M} 2 \\
\mathrm{SDH}-\mathrm{M} 1\end{array}$ & $\begin{array}{l}\text { Number of violations of access control requirements or } \\
\text { policies for survey data } \\
\text {-As a result, number of successful intrusions into } \\
\text { technology assets (digital data) or facility assets } \\
\text { (physical data) where survey data is stored, processed, } \\
\text { and transmitted } \\
\text { - As a result, number of instances of survey data } \\
\text { accessed in an unauthorized manner } \\
\text { - As a result, number of incidents declared } \\
\text { - As a result, number of breaches of confidentiality of } \\
\text { survey data } \\
\text { - As a result, number of violations of requirements for } \\
\text { survey data }\end{array}$ & $\begin{array}{l}\text { Data intrusions } \\
\text { Data violations }\end{array}$ & $\begin{array}{l}\text { Implementation; } \\
\text { possibly } \\
\text { Effectiveness }\end{array}$ & Base of type count & $3.0,4.0,6.0$ & $\begin{array}{l}\text { KIM:SG4.SP2 } \\
\text { KIM:SG5.SP1 } \\
\text { GG2.GP8 }\end{array}$ \\
\hline $\begin{array}{l}\text { DH-M3 } \\
\text { SDH-M2 }\end{array}$ & $\begin{array}{l}\text { Number of violations of survey data handling } \\
\text { requirements }\end{array}$ & Requirements & Implementation & Base of type count & $\begin{array}{l}1.0,3.0,4.0 \\
6.0\end{array}$ & KIM:SG4, SG5, SG6 \\
\hline $\begin{array}{l}\text { DH-M6 } \\
\text { SDH-M3 }\end{array}$ & Number of instances of survey data received or created & Data receipt & Implementation & Base of type count & 1.0 & $\begin{array}{l}\text { ADM:SG1.SP1 } \\
\text { ADM:SG3.SP2 } \\
\text { GG2.GP8 }\end{array}$ \\
\hline $\begin{array}{l}\text { DH-M7 } \\
\text { SDH-M4 }\end{array}$ & $\begin{array}{l}\text { Number of instances of survey data returned or } \\
\text { destroyed }\end{array}$ & $\begin{array}{l}\text { Data return or } \\
\text { destruction }\end{array}$ & Implementation & Base of type count & 6.0 & $\begin{array}{l}\text { ADM:SG1.SP1 } \\
\text { ADM:SG3.SP2 } \\
\text { GG2.GP8 }\end{array}$ \\
\hline $\begin{array}{l}\text { DH-M8 } \\
\text { SDH-M5 }\end{array}$ & $\begin{array}{l}\text { Elapsed time between creation or receipt of survey data } \\
\text { and the return of the data to the survey owner and/or its } \\
\text { destruction in any } A B C \text { facility or on any } A B C \text { technology } \\
\text { asset (mean, median) }\end{array}$ & $\begin{array}{l}\text { Data return or } \\
\text { destruction }\end{array}$ & Implementation & $\begin{array}{l}\text { Base of type } \\
\text { schedule }\end{array}$ & $1.0,6.0$ & $\begin{array}{l}\text { ADM:SG1.SP1 } \\
\text { ADM:SG3.SP2 } \\
\text { GG2.GP8 }\end{array}$ \\
\hline $\begin{array}{l}\text { DH-M9 } \\
\text { SDH-M6 }\end{array}$ & $\begin{array}{l}\text { Elapsed time (from initial request) to recover survey data } \\
\text { from backups (mean, median) }\end{array}$ & Data sustainment & Implementation & $\begin{array}{l}\text { Base of type } \\
\text { schedule }\end{array}$ & 8.0 & $\begin{array}{l}\text { KIM:SG6.SP1 } \\
\text { GG2.GP8 }\end{array}$ \\
\hline $\begin{array}{l}\text { DH-M10 } \\
\text { SDH-M7 }\end{array}$ & $\begin{array}{l}\text { Percentage of survey data recovered that does not } \\
\text { match the most current version of survey data backed } \\
\text { up (should be } 0 \% \text { ) }\end{array}$ & Data sustainment & Implementation & Derived & 8.0 & $\begin{array}{l}\text { KIM:SG6.SP1 } \\
\text { GG2.GP8 }\end{array}$ \\
\hline
\end{tabular}


Exit Criteria

- Survey data has been protected and sustained in accordance with requirements.

- Survey data has been returned or destroyed in accordance with requirements. 


\section{TEMPLATE}

\section{[Name] Procedure Definition}

\section{Purpose}

The purpose of the [procedure name] procedure is...

Scope

This procedure applies to...

\begin{tabular}{lr}
\hline Acronyms and Definitions \\
ACR1 & Definition \\
ACR2 & Definition
\end{tabular}

\section{Outputs}

[List the expected work product(s) produced from the activities of the procedure.]

\section{Entry Criteria}

[List the conditions that must be met for the procedure to begin.]

\section{Inputs}

[List the expected inputs to the procedure.]

$\bullet$

\section{References}

[List any documents and sources that guide the performance of the procedure. The procedure inherits all Requirements and Controls from its parent process unless otherwise stated.]

Policies

[List the relevant policies, acts, or regulations for the procedure.]

Processes

[List the processes that the procedure supports.]

Requirements

[List or reference the requirements relevant to the procedure.]

Standards

[List the relevant standards for the procedure.]

Guidelines

[List the relevant guidelines for the procedure.] 
Templates

[List the templates used in the procedure.]

Checklists

[List the checklists used in the procedure.]

Training

[List the training required for the procedure.]

Tools

[List tools used to implement the procedure.]

Roles

[Describe the roles that perform the procedure.]

\begin{tabular}{|l|l|l|l|}
\hline Role & $\begin{array}{l}\text { Number } \\
\text { of People }\end{array}$ & Description & Responsibility \\
\hline [role name] & $\begin{array}{l}\text { [number } \\
\text { range] }\end{array}$ & [role description] & [responsibilities of the role] \\
\hline & & & \\
\hline
\end{tabular}

\section{Activities}

[Describe the activities that compose the procedure.]

\begin{tabular}{|l|l|}
\hline Activity & Description \\
\hline $\begin{array}{l}\text { [activity number and name-each activity } \\
\text { should map directly to one or more activities } \\
\text { in the parent process definition] }\end{array}$ & [activity description, including the role(s) performing each sub- \\
activity]
\end{tabular}

\section{Swim Lane Diagram}

[If desired, show the relationship of roles responsible for performing procedure activities.]

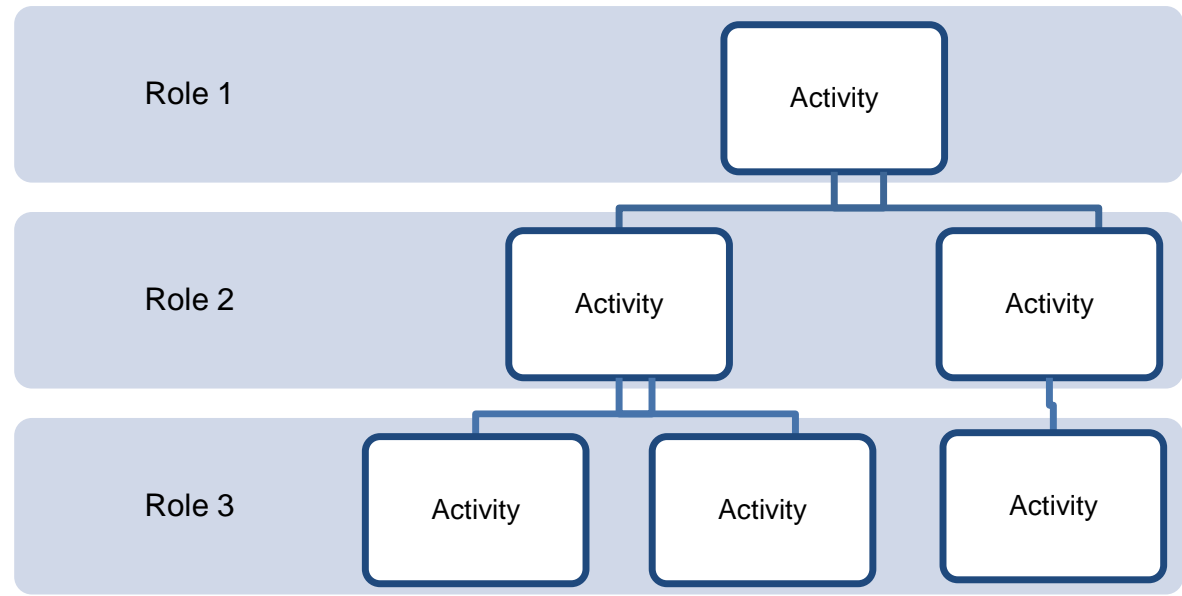




\section{Verification}

[Describe the verification activities that are necessary to confirm that the activities of the procedure have been adequately performed.]

The verification activities for the [procedure name] include the following:

\section{Measures}

[Describe the measures used to support management information needs for the procedure.]

\begin{tabular}{|l|l|l|l|l|l|}
\hline ID & Measure & $\begin{array}{l}\text { Type of } \\
\text { Information }\end{array}$ & Measure Type & $\begin{array}{l}\text { Base or } \\
\text { Derived }\end{array}$ & Activities \\
\hline & & & & & \\
\hline
\end{tabular}

[ID: A unique, sequential identifier assigned to each measure.]

[Measure: Measure description.]

[Type of Information: A category that can be used for affinity grouping of related measures. These can be work products (such as asset inventory and asset controls) or activities (such as change management and obligation satisfaction).]

[Measure Type: Implementation, effectiveness, or process performance.]

[Base or Derived: A base measure is a directly observable attribute of an asset, service, or resilience process; a derived measure is a mathematical function of two or more base and/or derived measures.]

[Activities: Assigned numbers of the activities in which the measure is collected.]

[For further definition of each column in the measures table, see Chapter 3 in Allen [2011].]

\section{Exit Criteria}

[List the conditions that must be satisfied for the procedure to be considered complete.] 


\section{Appendix C: Information Asset Profile Example and Template}

The information asset profile template in this section is a compilation of unpublished profile templates created by members of the Resilient Enterprise Management team and from profile information in the following sources:

- $\quad$ CERT ${ }^{\circledR}$ Resilience Management Model [Caralli 2011]

- Introducing OCTAVE Allegro [Caralli 2007]

- Information Asset Profiling [Stevens 2005]

The profile illustrates how an asset definition can

- $\quad$ link an information asset to the services in which it is used, to help ensure that any servicespecific requirements are considered in the development of resilience requirements for the asset

- $\quad$ list all of the ways in which the asset is stored, transported, and processed, to help ensure that all forms and locations of the asset are considered in the development of resilience requirements

- $\quad$ specify the asset’s resilience requirements

The example and template do not include a field for the value of the asset in either qualitative or quantitative terms. See Stevens [2005], pages 39-41, for guidance on developing an information asset valuation.

The profile could be adapted for other asset types, such as technology assets and facilities. The profile can also be customized for specific uses. The example contains three fields that are not in the template but that are needed to fully describe the asset: data collection objective, how collected and by whom, and collection frequency. 


\section{Survey Data Information Asset Profile}

\begin{tabular}{|c|c|}
\hline Profile date and version & September 17, 2011; v 0.1 \\
\hline Profile creator & Jerry Brekovny \\
\hline Data set name & Survey Data \\
\hline Data set description & $\begin{array}{l}\text { Data that external party (EP) staff provide to ABC Organization during their participation in a survey } \\
\text { project. Data may include presentations, reports, templates, process definitions, survey responses and } \\
\text { observations, and other artifacts that EP staff provide. }\end{array}$ \\
\hline Data collection objective & $\begin{array}{l}\text { The objective is to understand how the EP intends to use and is using CERT-RMM to improve its } \\
\text { organization's operational resilience to meet a specific improvement project objective. }\end{array}$ \\
\hline How collected and by whom & $\begin{array}{l}\text { Developed and provided by EP staff members to members of the ABC Organization Survey Team } \\
\text { (AST). The AST lead or co-lead takes possession of all survey data provided at each survey meeting } \\
\text { and between survey meetings via email and SharePoint. }\end{array}$ \\
\hline Collection frequency & $\begin{array}{l}\text { Survey data is collected at each survey meeting and between survey meetings via email or posts to } \\
\text { designated SharePoint sites. }\end{array}$ \\
\hline Primary use & Provides essential information to guide the EP in meeting their improvement project objective. \\
\hline Other acceptable uses & $\begin{array}{l}\text { Improvement of ABC's CERT-RMM-based processes and process assets; improvement of ABC’s } \\
\text { survey process }\end{array}$ \\
\hline Data owner & EP organizations \\
\hline Services that use this asset & Not applicable \\
\hline
\end{tabular}




\begin{tabular}{|l|l|l|l|}
\hline $\begin{array}{l}\text { Where stored (including backups } \\
\text { and duplicates) }\end{array}$ & \multicolumn{1}{|c|}{ Form } & \multicolumn{1}{c|}{ Device and location } & \multicolumn{1}{c|}{ Custodian } \\
\cline { 2 - 4 } & Email & MS Outlook email server & ABC IT administrator \\
\hline Email & Local mail on AST laptops & $\begin{array}{l}\text { AST lead or co-lead } \\
\text { AST member }\end{array}$ \\
\hline Email & $\begin{array}{l}\text { Local mail on AST desktop } \\
\text { machines }\end{array}$ & $\begin{array}{l}\text { AST lead or co-lead } \\
\text { AST member }\end{array}$ \\
\hline $\begin{array}{l}\text { Survey data } \\
\text { (physical) }\end{array}$ & $\begin{array}{l}\text { Locked file cabinet or desk in a } \\
\text { AST member's office }\end{array}$ & $\begin{array}{l}\text { AST lead or co-lead } \\
\text { AST member }\end{array}$ \\
\hline $\begin{array}{l}\text { Survey data } \\
\text { digital) }\end{array}$ & $\begin{array}{l}\text { SharePoint server (internal) } \\
\text { SharePoint server (external) }\end{array}$ & $\begin{array}{l}\text { AST lead or co-lead } \\
\text { AST member } \\
\text { ABC IT administrator }\end{array}$ \\
\hline $\begin{array}{l}\text { Survey data } \\
\text { (digital) }\end{array}$ & $\begin{array}{l}\text { AST laptops } \\
\text { Survey data } \\
\text { (digital) }\end{array}$ & AST desktops & $\begin{array}{l}\text { AST lead or co-lead } \\
\text { AST member }\end{array}$ \\
\hline
\end{tabular}




\begin{tabular}{|c|c|c|c|c|}
\hline \multirow[t]{3}{*}{ Where processed } & \multicolumn{2}{|c|}{ System or application } & \multicolumn{2}{|r|}{ Custodian } \\
\hline & \multicolumn{2}{|c|}{ MS Office 2007 (Word, PowerPoint, Excel) } & \multicolumn{2}{|c|}{$\begin{array}{l}\text { AST lead or co-lead } \\
\text { AST member }\end{array}$} \\
\hline & \multicolumn{2}{|l|}{ MS Outlook 2007} & \multicolumn{2}{|c|}{$\begin{array}{l}\text { AST lead or co-lead } \\
\text { AST member }\end{array}$} \\
\hline \multirow[t]{6}{*}{ How transported } & Form & \multicolumn{2}{|c|}{ Device or method } & Custodian \\
\hline & Email messages & \multicolumn{2}{|c|}{ Email; MS Outlook 2007} & $\begin{array}{l}\text { AST lead or co-lead } \\
\text { AST member }\end{array}$ \\
\hline & Survey data (paper) & \multicolumn{2}{|c|}{$\begin{array}{l}\text { By hand, from EP meeting site } \\
\text { to office }\end{array}$} & $\begin{array}{l}\text { AST lead or co-lead } \\
\text { AST member }\end{array}$ \\
\hline & $\begin{array}{l}\text { Survey data } \\
\text { (digital) }\end{array}$ & \multicolumn{2}{|c|}{$\begin{array}{l}\text { Email attachment; MS Outlook } \\
2007\end{array}$} & $\begin{array}{l}\text { AST lead or co-lead } \\
\text { AST member }\end{array}$ \\
\hline & $\begin{array}{l}\text { Survey data } \\
\text { (digital) }\end{array}$ & \multicolumn{2}{|c|}{$\begin{array}{l}\text { Laptop, between office and } \\
\text { home }\end{array}$} & $\begin{array}{l}\text { AST lead or co-lead } \\
\text { AST member }\end{array}$ \\
\hline & $\begin{array}{l}\text { Survey data } \\
\text { (digital) }\end{array}$ & \multicolumn{2}{|c|}{ SharePoint server (external) } & $\begin{array}{l}\text { AST lead or co-lead } \\
\text { AST member }\end{array}$ \\
\hline Sensitivity category & \multicolumn{4}{|l|}{ Unclassified sensitive } \\
\hline
\end{tabular}




\begin{tabular}{|c|c|c|}
\hline \multirow{10}{*}{$\begin{array}{l}\text { Resilience requirements and } \\
\text { strategies }\end{array}$} & Confidentiality requirements & Confidentiality strategy \\
\hline & $\begin{array}{l}\text { ABC Organization Code of Business Ethics and } \\
\text { Compliance requirements for controlled } \\
\text { information }\end{array}$ & $\begin{array}{l}\text { AST members (including AST lead and AST co- } \\
\text { lead) and all ABC staff members who participate } \\
\text { in survey projects understand by agreement that no } \\
\text { survey data is to be shared with anyone other than } \\
\text { survey participants without explicit, written } \\
\text { member permission. } \\
\text { Only AST members have access to survey data. }\end{array}$ \\
\hline & Integrity requirements & Integrity strategy \\
\hline & $\begin{array}{l}\text { ABC Organization Code of Business Ethics and } \\
\text { Compliance requirements for controlled } \\
\text { information }\end{array}$ & $\begin{array}{l}\text { Same access controls used for confidentiality } \\
\text { strategy. }\end{array}$ \\
\hline & Availability requirements & Availability strategy \\
\hline & $\begin{array}{l}\text { Survey data must be accessible on SharePoint } \\
\text { from 6:00 a.m. to 11:00 p.m. daily. } \\
\text { Survey data must be retrievable via restore from } \\
\text { backup. }\end{array}$ & $\begin{array}{l}\text { The SharePoint site is available 24/7. } \\
\text { Digital data is backed up by ABC IT in accordance } \\
\text { with the posted service level agreement. All } \\
\text { backups are encrypted. } \\
\text { The ability to restore digital data from backups is } \\
\text { regularly tested in accordance with the posted } \\
\text { service level agreement. }\end{array}$ \\
\hline & Privacy requirements & Privacy strategy \\
\hline & None & Not applicable \\
\hline & Other requirements & Strategy \\
\hline & As identified by EP staff for specific survey data & Same as confidentiality strategy. \\
\hline
\end{tabular}




\section{Information Asset Profile Template}

\begin{tabular}{|l|l|}
\hline Profile date and version & Create a version number that follows a standard, enterprise-wide convention. \\
\hline Profile creator & Name, role or position, and contact information of the person or persons who wrote the profile. \\
\hline Data set name & Descriptive name for the data set (not a file name). \\
\hline Data set description & $\begin{array}{l}\text { Describe the contents of the information asset in enough detail to ensure that the boundaries of the asset are } \\
\text { clear. (See Stevens [2005], pages 25-28, for further information.) }\end{array}$ \\
\hline Primary use & Describe the primary purpose for which the asset is used. \\
\hline Other acceptable uses & $\begin{array}{l}\text { Describe secondary purposes for which the asset is used (if applicable, the only other purposes for which it may } \\
\text { be used). }\end{array}$ \\
\hline Data set owner & $\begin{array}{l}\text { Role or position and department; organization name if it is an external entity; and contact information for the } \\
\text { person currently acting in the role. }\end{array}$ \\
\hline Services that use this asset & $\begin{array}{l}\text { Services is used in the sense of “activities that the organization carries out in the performance of a duty or in the } \\
\text { production of a product” [Caralli 2011]. An IT service, for example, might be help desk support; an information } \\
\text { asset used in that service might be the service request database. }\end{array}$ \\
\hline
\end{tabular}




\begin{tabular}{|c|c|c|c|c|}
\hline \multirow{2}{*}{$\begin{array}{l}\text { Where stored (including } \\
\text { backups and duplicates) }\end{array}$} & Form & \multicolumn{2}{|c|}{ Device and Location } & Custodian \\
\hline & $\begin{array}{l}\text { A single information asset may } \\
\text { be instantiated in many forms } \\
\text { (Access database, Excel file, } \\
\text { PDF, HTML file, paper copy, } \\
\text { etc.). Include a Form/Device and } \\
\text { Location/Custodian row for each } \\
\text { form of the asset. }\end{array}$ & \multicolumn{2}{|c|}{$\begin{array}{l}\text { Device type (server, laptop, } \\
\text { PDA, tape, CD, USB flash drive, } \\
\text { safe, etc.) and any name or other } \\
\text { identifier, and, as applicable, } \\
\text { device location-physical (such } \\
\text { as a room number and a building } \\
\text { name and address) and/or virtual } \\
\text { (such as a SharePoint library } \\
\text { address). }\end{array}$} & $\begin{array}{l}\text { "Asset custodians are persons or } \\
\text { organizational units, internal or } \\
\text { external to the organization, that } \\
\text { agree to and are responsible for } \\
\text { implementing and managing } \\
\text { controls to satisfy the resilience } \\
\text { requirements of high-value assets } \\
\text { while they are in their care" } \\
\text { [Caralli 2011, pg. 33]. Enter the } \\
\text { custodian's role/position and } \\
\text { department; organization name if } \\
\text { it is an external entity; and } \\
\text { contact information for the person } \\
\text { currently acting in the role. }\end{array}$ \\
\hline \multirow[t]{2}{*}{ Where processed } & \multicolumn{2}{|c|}{ System or application } & \multicolumn{2}{|r|}{ Custodian } \\
\hline & \multicolumn{2}{|c|}{$\begin{array}{l}\text { Systems and applications are temporary } \\
\text { "containers" of data and should therefore be } \\
\text { considered in the development of resilience } \\
\text { requirements for the asset. }\end{array}$} & \multicolumn{2}{|l|}{ Same as above. } \\
\hline \multirow[t]{2}{*}{ How transported } & Form & \multicolumn{2}{|c|}{ Device or method } & Custodian \\
\hline & Same as above. & \multicolumn{2}{|c|}{$\begin{array}{l}\text { Network or network segment } \\
\text { (specify wired or wireless), email } \\
\text { application, FedEx, etc. }\end{array}$} & Same as above. \\
\hline Sensitivity category & \multicolumn{4}{|c|}{$\begin{array}{l}\text { "Sensitivity is a measure of the degree to which an information asset must be protected based on the } \\
\text { consequences of its unauthorized access, modification, or disclosure" [Caralli 2011, pg. 514]. Specify the } \\
\text { appropriate category from your organization's information asset sensitivity categorization scheme, if applicable } \\
\text { Examples of sensitivity categories are public, internal use only, confidential, proprietary, and secret. }\end{array}$} \\
\hline
\end{tabular}




\begin{tabular}{|c|c|c|}
\hline \multirow{10}{*}{$\begin{array}{l}\text { Resilience requirements } \\
\text { and strategies }\end{array}$} & Confidentiality requirements & Confidentiality strategy \\
\hline & $\begin{array}{l}\text { Specify all requirements related to restricting } \\
\text { access to the asset to authorized people, processes, } \\
\text { and devices, citing any relevant policies, rules, } \\
\text { laws, and regulations to which the asset is subject. }\end{array}$ & $\begin{array}{l}\text { List the administrative, technical, and/or physical } \\
\text { controls that are required to meet the specified } \\
\text { confidentiality requirements. }\end{array}$ \\
\hline & Integrity requirements & Integrity strategy \\
\hline & $\begin{array}{l}\text { Specify all requirements related to maintaining the } \\
\text { asset in the condition intended by its owner so it } \\
\text { will continue to be useful for the purposes intended } \\
\text { by the owner, citing any relevant policies, rules, } \\
\text { laws, and regulations to which the asset is subject. }\end{array}$ & $\begin{array}{l}\text { List the administrative, technical, and/or physical } \\
\text { controls that are required to meet the specified } \\
\text { integrity requirements. }\end{array}$ \\
\hline & Availability requirements & Availability strategy \\
\hline & $\begin{array}{l}\text { Specify all requirements related to ensuring that the } \\
\text { asset is accessible to authorized users (people, } \\
\text { processes, and devices) whenever it is needed, } \\
\text { citing any relevant policies, rules, laws, and } \\
\text { regulations to which the asset is subject. }\end{array}$ & $\begin{array}{l}\text { List the administrative, technical, and/or physical } \\
\text { controls that are required to meet the specified } \\
\text { availability requirements. }\end{array}$ \\
\hline & Privacy requirements & Privacy strategy \\
\hline & $\begin{array}{l}\text { Specify all requirements related to ensuring that } \\
\text { information about individuals is disclosed only to } \\
\text { people, processes, and devices authorized by those } \\
\text { individuals or permitted under privacy laws and } \\
\text { regulations. }\end{array}$ & $\begin{array}{l}\text { List the administrative, technical, and/or physical } \\
\text { controls that are required to meet the specified } \\
\text { privacy requirements. }\end{array}$ \\
\hline & Other requirements & Strategy \\
\hline & $\begin{array}{l}\text { Enter any requirements that don't fit in the } \\
\text { previous categories, such as unique requirements } \\
\text { arising from contractual specifications for } \\
\text { resilience. }\end{array}$ & $\begin{array}{l}\text { List the administrative, technical, and/or physical } \\
\text { controls that are required to meet other } \\
\text { requirements. }\end{array}$ \\
\hline
\end{tabular}




\section{Appendix D: Alternative Process or Procedure Example and Template}

One of the members of the CERT-RMM Users Group generously shared a generic template derived from what they use for both process and procedure definitions, along with an Asset Definition Process example. The example appears first, followed by the template.

\section{Process}

\section{Asset Definition}

Copyright 2011

Issue:

Effective:

Approval:

Controlled by:

Process Owner:
A hard copy of this document may not be current. The current issue is on the Company Intranet.

\section{PURPOSE}

The purpose of this process is to ensure that Engineering groups identify and document organizational assets to ensure sustained productivity to support Engineering services.

\section{SCOPE \& APPLICABILITY}

This process applies to every group within the Engineering organization.

\section{GENERAL}

Identifying and documenting high value organizational assets is critical to ensuring a sustainable organization, especially in times of adversity and risk.

\section{RESPONSIBILITIES}

\section{Engineering Manager}

1. Identify and document group's involvement in critical services

2. Identify and document assets, including people, information, technology and facilities

3. Review assets with team

4. Get approval from Engineering Review Board for new and updated assets

\section{Engineering Group}

1. Review assets documented by Engineering Manager

\section{Engineering Review Board}

1. Review and approve assets documented by Engineering Manager

2. Identify and document conflicts and dependencies between Engineering Groups.

\section{ENTRY CRITERIA}

1. Senior Executive Management has identified or updated high-value Engineering services as defined in the yearly goals and objectives. 


\section{INPUT}

1. Organizational charts

2. Support Systems Database

\section{IMPLEMENTATION}

On a yearly basis, or when Senior Executive Management updates the goals and objectives:

1. The Engineering Manager identifies the Engineering Group's involvement in critical services and documents this involvement in a Mission Statement.

2. For each critical service, the Engineering Manager identifies the critical staff for performing that service, including name, employee number, role in providing the service, and position in the organization (or in another organization). Critical staff is documented in the Support Systems Database.

3. For each critical service, the Engineering Manager identifies any information required by the service. This includes any records, files, processes and procedures needed to provide the service. The protection level of this information must also be identified (i.e., no restrictions, sensitive, proprietary, confidential, export controlled, or a combination) as well as the location (URL, SharePoint address, or physical location) and the organizational owner of the information. Critical information is documented in the Support Systems Database, including a brief description of the information.

4. For each critical service, the Engineering Manager identifies any tools or applications needed in performing the critical service. This would include any databases, automated forms, software, hardware, or COTS used. It does not need to go to the server or cable level (these assets are identified by the Computer Services organization). The location of the tool or application (URL, SharePoint address, or physical location) must be identified, as well as the organizational owner of the tool / application. Critical technology assets are documented in the Support Systems Database.

5. If there are facilities used for the critical services that are not provided by the company (i.e., work in non-company owned facilities), the Engineering Manager identifies these facilities in the Support Systems Database. (Company owned facilities are identified by the Facilities organization.) This will include the address, facility owner, location within the facility, and requirements for entry into the facility.

6. Once documented in the Support Systems Database, the Engineering Manager will review the entries with her/his Engineering Group to ensure both correctness and communication. The Engineering Manager will then submit new items or updates to the Engineering Review Board for review and approval.

7. The Engineering Review Board will review the new or updated items in the Support Systems Database. This review will be done for correctness, consistency of approach and the identification of any conflicts or dependencies with other Engineering groups.

\section{OUTPUT}

1. Mission Statement

2. Updates to Support Systems Database

\section{EXIT CRITERIA}

1. Engineering Review Board approves the new and updated entries in the Support Systems Database.

\section{MEASUREMENTS}

1. Number of staff assets changed (modified, added and deleted)

2. Number of information assets changed (modified, added and deleted)

3. Number of technology assets changed (modified, added and deleted) 
4. Number of facilities assets changed (modified, added and deleted)

\section{INFORMATION LINKS}

Process Assets:

- ENG120, Engineering Review Board Submittal Process

Sources and References:

- Corporate Policy, 123 Resource Identification and Protection

General Information:

- $\quad$ CERT ${ }^{\circledR}$ Resilience Management Model, Version 1.1

REVISION HIGHLIGHTS

\begin{tabular}{|c|c|c|c|}
\hline Issue & Published & Author & Summary of Improvements \\
\hline 1 & April 2011 & I.M. Theauthor & New document \\
\hline
\end{tabular}


Process or Procedure Template Replace with "Process" or "Procedure" or similar heading (i.e., there may be cases where this is a form or checklist rather than a process or procedure)

\section{TITLE}

Replace "Title" with a descriptive title for this process element (note that process element will be used as a generic term to refer to either the Process or the Procedure). Also put this Title in "Subject" box of File/Properties.

Copyright 2011 \{optional\}

A hard copy of this document may not be current. The current issue is on the \{add location\}.

Issue:

$<$ If this is a new process element, leave the Issue number as "1". If this is a revision, increment the number by 1.>

Effective:

Date < Use the following format for the effective date: Month, Year e.g., February 2009>

Approval: $\quad$ PPosition that approves the process / procedure\}

Controlled by: $\quad$ \{Position that controls the process / procedure\}

\{Position that owns the process / procedure\} (Point of Contact email

Process Owner: address)Insert the email address of the Point of Contact to whom you want suggestions and revision update notices sent. Also put this name in "Author" box of File/Properties.>

\section{PURPOSE}

Describe why this process or procedure is needed in two sentences or less. Include a reference to any policy that this process or procedure implements.

\section{SCOPE \& APPLICABILITY}

Describe the scope of the process or procedure (e.g., applies to all employees, applies to a particular role or activity within a function, etc.)

\section{GENERAL}

This section includes any information which is helpful in understanding the context for the process element but is not explicitly a part of the process element. Background information, clarifications, and specific terms used in the asset may be included. Note that definitions can be added here.

- A Process is "what" to do - a Set of interrelated or interacting activities which transforms inputs into outputs.

- A Procedure is "how" to do it - a logical set of instructions to carry out an activity or process.

\section{RESPONSIBILITIES}

This section lists the responsibilities of the agents that have a role in the activities or instructions listed in the Implementation section.

Responsible Party \#1Replace "Responsible Party \#1" with the role of WHO is primarily responsible for some or all of the implementation of this process element.

1. Responsibilities Replace "Responsibilities" with actual responsibilities for this WHO.

Other Responsible Party Replace "Other Responsible Party" with a role of another WHO (if applicable) that is responsible for parts of this process element. This is usually the WHO that has some supporting role in this process element. List as many as necessary.

1. Responsibilities. Replace "Responsibilities" with actual responsibilities for this other WHO. 


\section{ENTRY CRITERIA}

1. This section states conditions that should exist before process element execution.

\section{INPUT}

1. This section lists the artifacts and sources that may be required or be of assistance in performing the activities.

\section{IMPLEMENTATION}

1. This section describes activities and directions with details of how to, when, where and by whom. A process flow diagram can be added for clarification of the implementation.

\section{OUTPUT}

1. This section lists the artifacts produced by the activities and their destination.

\section{EXIT CRITERIA}

1. This section states conditions that should exist for the process element to terminate.

\section{MEASUREMENTS}

1. This section contains measures that should be obtained during process element execution to measure policy or process effectiveness. This section should state the measurement definition and when it should be obtained. The measurement data should be collected, tracked and made available for process improvement.

\section{INFORMATION LINKS}

\section{Process Assets:}

- Titles Insert TITLES of process elements (policy, process, procedure, instruction or form) that help implement, support or relate to this process or procedure. Provide a link to the asset as well as the title. Note: If any process element is not available via a link, provide the name and phone number of a point of contact from whom a copy can be obtained.

\section{Sources and References:}

- Titles Insert TITLES of a source which caused the issuing of this process element (e.g., Corporate policy) or a reference that is embedded in the text of this process element. Provide a link to the asset as well as the title. Note: If any of these are not available via a link, provide the name and phone number of a point of contact from whom a copy can be obtained.

\section{General Information:}

- Titles and Links - Insert the TITLES and LINKS of any documents or data that provide general information on the subject matter of the process element. This might be a link to the home page of the process owner of this process element or another related organizational home page, e.g., Software Engineering Institute, IEEE or a government regulatory site.

\section{REVISION HIGHLIGHTS}

\begin{tabular}{|c|c|c|c|}
\hline Issue & Published & Author & Summary of Improvements \\
\hline$\#$ & $\begin{array}{c}\text { Same as the } \\
\text { effective date at } \\
\text { the top of the } \\
\text { template }\end{array}$ & Name & $\begin{array}{c}\text { New document or, if a revision, provide a } \\
\text { summary of the changes }\end{array}$ \\
\hline
\end{tabular}




\section{APPENDICES*}

It is recommended to use the Information Links section or create a form instead of using an appendix. However, appendices could contain additional information to implement this process element e.g., checklists, computer tools and utilities, etc. 


\section{Appendix E: Measure Definition Example and Template}

\begin{tabular}{|c|c|c|c|c|}
\hline Measure Name and ID & \multicolumn{4}{|c|}{$\begin{array}{l}\text { Number of breaches of confidentiality and privacy traced to violations of } \\
\text { access control policies for information assets (DH-M2) }\end{array}$} \\
\hline Goal & \multicolumn{4}{|c|}{ Protect designated data } \\
\hline Question(s) & \multicolumn{4}{|c|}{$\begin{array}{l}\text { How many breaches of confidentiality and, if applicable, privacy occurred } \\
\text { as a result of unauthorized access of designated data in a specific time } \\
\text { period? }\end{array}$} \\
\hline $\begin{array}{l}\text { Related Processes and } \\
\text { Procedures }\end{array}$ & \multicolumn{4}{|c|}{$\begin{array}{l}\text { Data Handling Process } \\
\text { Survey Data Handling Procedure } \\
\text { Diagnostic Data Handling Procedure } \\
\text { Performance Data Handling Procedure }\end{array}$} \\
\hline Visual Display & \multicolumn{4}{|c|}{$\begin{array}{c}\text { Number of Information Asset } \\
\text { Breaches }\end{array}$} \\
\hline \multirow{3}{*}{$\begin{array}{l}\text { Data Input(s) } \\
\text { Data elements } \\
\text { Data type }\end{array}$} & \multicolumn{2}{|c|}{ Start date of last reporting period } & \multicolumn{2}{|c|}{ Base measure of type "schedule" } \\
\hline & \multicolumn{2}{|c|}{ End date of last reporting period } & \multicolumn{2}{|c|}{ Base measure of type "schedule" } \\
\hline & \multicolumn{2}{|c|}{ Root causes of incidents } & & \\
\hline $\begin{array}{l}\text { Data Collection } \\
\text { How } \\
\text { When/how often } \\
\text { By whom }\end{array}$ & \multicolumn{4}{|c|}{$\begin{array}{l}\text { - On an event-driven basis, the organization's service desk personnel } \\
\text { and CSIRT collect information about an incident throughout its life } \\
\text { cycle. } \\
\text { Information is reviewed either when the incident is closed } \\
\text { (IMC:SG4.SP4 Close Incidents) or when the post-incident review is } \\
\text { performed (IMC:SG5.SP1 Perform Post-Incident Review). } \\
\text { - The CSIRT maintains a list of root causes of incidents and updates it } \\
\text { after each post-incident review. } \\
\text { - Information about information assets is maintained in the asset }\end{array}$} \\
\hline
\end{tabular}

12 Allen [2010] provides a template for defining base measures. 


\begin{tabular}{|c|c|c|}
\hline & \multicolumn{2}{|c|}{$\begin{array}{l}\text { inventory/database/profiles (ADM:SG1 Establish Organizational } \\
\text { Assets; KIM:SG1 Establish and Prioritize Information Assets; TM:SG1 } \\
\text { Establish and Prioritize Technology Assets). }\end{array}$} \\
\hline $\begin{array}{l}\text { Data Reporting } \\
\text { By/to whom } \\
\text { When/how often }\end{array}$ & \multicolumn{2}{|c|}{$\begin{array}{l}\text { - The CSIRT reports data to the CISO. } \\
\text { - } \quad \text { Data is reported once per reporting period. }\end{array}$} \\
\hline $\begin{array}{l}\text { Data Storage } \\
\text { Where } \\
\text { How } \\
\text { Access control }\end{array}$ & \multicolumn{2}{|c|}{ 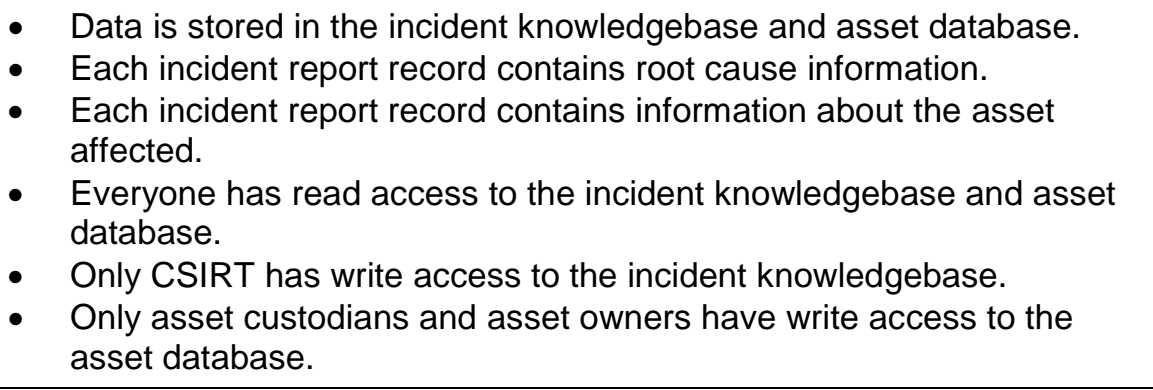 } \\
\hline $\begin{array}{l}\text { Stakeholders } \\
\text { Information owner(s) } \\
\text { Information customer(s) }\end{array}$ & \multicolumn{2}{|c|}{$\begin{array}{l}\text { - The CISO is the owner of the incident knowledgebase. } \\
\text { - The CISO and senior management are the customers for this } \\
\text { information. } \\
\text { The incident owner is responsible for maintaining and presenting all } \\
\text { information related to an incident. } \\
\text { - Asset custodians are responsible for maintaining and presenting all } \\
\text { information related to an information asset and the technology asset(s) } \\
\text { on which the incident occurs. } \\
\text { - The staff assigned to incident management are responsible for } \\
\text { executing the incident management process (IMC:SG1.SP2 Assign } \\
\text { Staff to the Incident Management Plan). }\end{array}$} \\
\hline \multirow[t]{13}{*}{ Algorithm or Formula } & \multicolumn{2}{|c|}{$\begin{array}{l}\text { Each incident record in the incident knowledgebase must contain the } \\
\text { following information: }\end{array}$} \\
\hline & Variable & Type \\
\hline & Date of occurrence & Date \\
\hline & $\begin{array}{l}\text { Assets, services, and } \\
\text { organizational units affected by } \\
\text { incident }\end{array}$ & $\begin{array}{l}\text { Asset ID, service ID, organizational } \\
\text { unit ID }\end{array}$ \\
\hline & Root cause & Name or label \\
\hline & \multicolumn{2}{|l|}{ Other information needed: } \\
\hline & Variable & Type \\
\hline & Start of reporting period & Date \\
\hline & End of reporting period & Date \\
\hline & Reporting interval & Quarter, month, or week \\
\hline & List of root causes & Names or labels \\
\hline & List of assets & Names or IDs \\
\hline & Number of breaches & Zero or positive integer \\
\hline
\end{tabular}




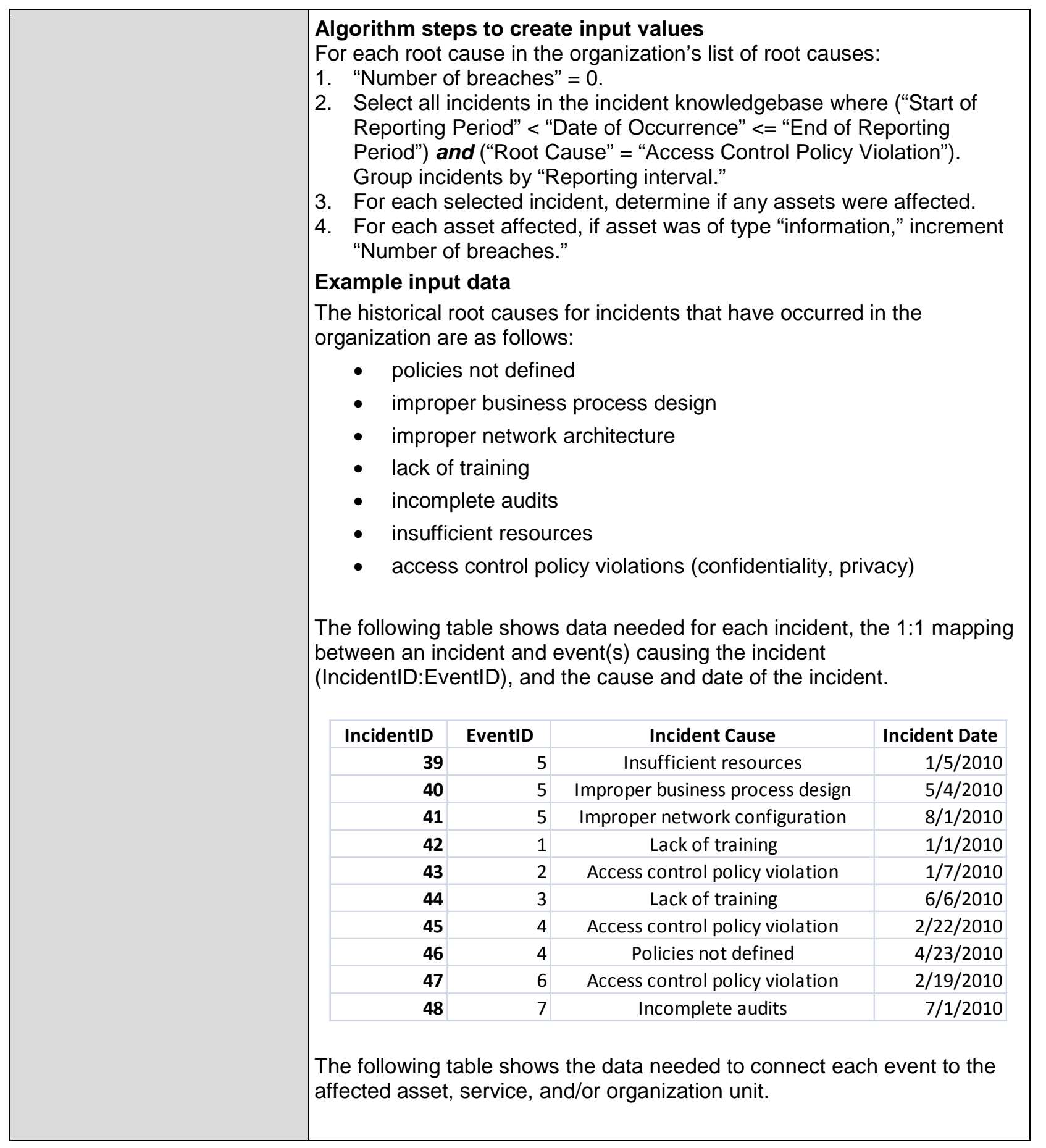




\begin{tabular}{|c|c|c|c|c|c|c|}
\hline & Eventn & Mapping ID & EventID & AssetID & ServicelD & OrgUnitID \\
\hline & & 1 & 2 & 1 & 1 & \\
\hline & & 2 & 2 & 6 & 1 & \\
\hline & & 3 & 4 & & & 1 \\
\hline & & 4 & 6 & 2 & & \\
\hline & & 5 & 6 & 3 & & \\
\hline & & 6 & 6 & 4 & & \\
\hline & & 7 & 6 & 5 & & \\
\hline & & 8 & 6 & & & 2 \\
\hline & $\begin{array}{l}\text { The follow } \\
\text { an asset } p\end{array}$ & $\begin{array}{l}\text { ving tables sho } \\
\text { profile. }\end{array}$ & low the da & ta needec & d to describ & e the asset type in \\
\hline & AssetID & AssetType & AssetSe & nsitivity & & \\
\hline & 1 & Information & $\mathrm{Hi}$ & gh & & \\
\hline & 2 & Facilities & $\mathrm{Hi}$ & gh & & \\
\hline & 3 & Technology & $\mathrm{Hi}$ & gh & & \\
\hline & 4 & Information & $\mathrm{Hi}$ & gh & & \\
\hline & 5 & Information & Lo & $w$ & & \\
\hline & 6 & People & Mec & lium & & \\
\hline & Example & output data & & & & \\
\hline & Month & $\begin{array}{c}\text { Number of } \\
\text { Breaches }\end{array}$ & & & & \\
\hline & Jan & 1 & & & & \\
\hline & Feb & 3 & & & & \\
\hline & Mar & 0 & & & & \\
\hline & Apr & 0 & & & & \\
\hline & May & 0 & & & & \\
\hline & Jun & 0 & & & & \\
\hline & Jul & 9 & & & & \\
\hline & Aug & 0 & & & & \\
\hline & Sep & & & & & \\
\hline & Oct & & & & & \\
\hline & Nov & & & & & \\
\hline & Dec & & & & & \\
\hline & $\begin{array}{l}\text { Plot Month } \\
\text { (breaches }\end{array}$ & $\begin{array}{l}\text { hs as labels o } \\
\text { ) on the } Y \text { axi }\end{array}$ & $\begin{array}{l}\text { in the } X a \\
\text { is. }\end{array}$ & xis, with $C$ & Count of Un & authorized Access \\
\hline $\begin{array}{l}\text { Interpretation or Expected } \\
\text { Value(s) }\end{array}$ & $\begin{array}{l}\text { The bar ch } \\
\text { assets res } \\
\text { current ye } \\
\text { security pa }\end{array}$ & $\begin{array}{l}\text { hart shows the } \\
\text { sulting from ac } \\
\text { ar to date. Sic } \\
\text { attern worth in }\end{array}$ & $\begin{array}{l}\text { e number } \\
\text { ccess con } \\
\text { gnificant } \\
\text { nvestigati }\end{array}$ & $\begin{array}{l}\text { of unauth } \\
\text { trol policy } \\
\text { variation a } \\
\text { ng. }\end{array}$ & $\begin{array}{l}\text { horized acc } \\
\text { y violations } \\
\text { among mon }\end{array}$ & $\begin{array}{l}\text { esses to information } \\
\text { per month for the } \\
\text { ths may indicate a }\end{array}$ \\
\hline
\end{tabular}




\begin{tabular}{|c|c|}
\hline Measure Name and ID & $\begin{array}{l}\text { Unique name and identifier for the measure. For example: Number } \\
\text { of resilience requirements (RR_03). }\end{array}$ \\
\hline Goal & $\begin{array}{l}\text { Statement of resilience goal. The goal should be connected to } \\
\text { overall organizational strategic goals and critical success factors, } \\
\text { organizational resilience goals, service resilience goals, and/or } \\
\text { asset resilience goals. }\end{array}$ \\
\hline Question(s) & $\begin{array}{l}\text { What question(s) is the measure intending to answer? For } \\
\text { example: How many incidents occurred last quarter? The question } \\
\text { should relate to the goal. }\end{array}$ \\
\hline $\begin{array}{l}\text { Related Processes and } \\
\text { Procedures }\end{array}$ & $\begin{array}{l}\text { List of the names of the process and procedures where this } \\
\text { measure is collected, including process and procedure measure } \\
\text { IDs if applicable. }\end{array}$ \\
\hline Visual Display & $\begin{array}{l}\text { Graphical depiction of the measure. For example: trend over time, } \\
\text { percentages, cumulative results, Pareto analysis, frequency } \\
\text { diagrams, etc. }\end{array}$ \\
\hline $\begin{array}{l}\text { Data Input(s) } \\
\text { Data Elements } \\
\text { Data Type }\end{array}$ & $\begin{array}{l}\text { All data elements (including measure name and ID, if applicable) } \\
\text { and their type (base or derived) used as input for this measure. }\end{array}$ \\
\hline $\begin{array}{l}\text { Data Collection } \\
\text { How } \\
\text { When/How Often } \\
\text { By Whom }\end{array}$ & $\begin{array}{l}\text { How the data will be collected (process), when and how often the } \\
\text { data will be collected (event driven, periodic), and who will collect } \\
\text { the data (people, tool). Refer to forms or standards if needed. }\end{array}$ \\
\hline $\begin{array}{l}\text { Data Reporting } \\
\text { By/To Whom } \\
\text { When/How Often }\end{array}$ & $\begin{array}{l}\text { The role that is responsible for reporting the measure. Identify for } \\
\text { whom (what role) the report is intended. This may be an individual } \\
\text { role or an organizational unit. }\end{array}$ \\
\hline $\begin{array}{l}\text { Data Storage } \\
\text { Where } \\
\text { How } \\
\text { Access Control }\end{array}$ & $\begin{array}{l}\text { Where the data is to be stored. Identify the storage media, } \\
\text { procedures, and tools for configuration control. Specify how } \\
\text { access to this data is controlled. }\end{array}$ \\
\hline $\begin{array}{l}\text { Stakeholders } \\
\text { Information Owner(s) } \\
\text { Information Collector(s) } \\
\text { Information Customer(s) }\end{array}$ & $\begin{array}{l}\text { Who will use this measure? How? What are the roles? Examples: } \\
\text { asset owner, service owner, line of business manager, business } \\
\text { continuity manager, steering group responsible for all aspects of } \\
\text { resilience, including resilience measurement. Consider } \\
\text { stakeholders external to the organization. }\end{array}$ \\
\hline Algorithm or Formula & $\begin{array}{l}\text { The algorithm or formula required to combine data elements to } \\
\text { create input values for the measure. It may be very simple, such } \\
\text { as input1/input2, or it may be much more complex. The } \\
\text { relationship between the algorithm and the visual display should } \\
\text { be explained as well. }\end{array}$ \\
\hline $\begin{array}{l}\text { Interpretation or Expected } \\
\text { Value(s) }\end{array}$ & $\begin{array}{l}\text { What different values of the measure mean. Make it clear how the } \\
\text { measure answers the goal-related Question(s) above. Provide any } \\
\text { important cautions about how the measure could be } \\
\text { misinterpreted and actions to avoid misinterpretation. Provide } \\
\text { guidance on how to interpret the measure and also what not to do } \\
\text { with the measure. If the measure has a target value or range for } \\
\text { success (meeting the goal), include that here. }\end{array}$ \\
\hline
\end{tabular}




\section{References}

URLs are valid as of the publication date of this document.

\section{[Allen 2010]}

Allen, Julia, \& Davis, Noopur. Measuring Operational Resilience Using the CERT ${ }^{\circledR}$ Resilience Management Model (CMU/SEI-2010-TN-030). Software Engineering Institute, Carnegie Mellon University, September 2010. http://www.sei.cmu.edu/library/abstracts/reports/10tn030.cfm

\section{[Allen 2011]}

Allen, Julia, \& Curtis, Pamela D. Measures for Managing Operational Resilience (CMU/SEI2011-TR-019). Software Engineering Institute, Carnegie Mellon University, September 2011. http://www.sei.cmu.edu/library/abstracts/reports/11tr019.cfm

\section{[Brassard 2010]}

Brassard, Michael \& Ritter, Diane. The Memory Jogger 2: A Pocket Guide of Tools for Continuous Improvement and Effective Planning, $2^{\text {nd }}$ edition. GOAL/QPC, 2010.

\section{[Caralli 2011]}

Caralli, Richard A., Allen, Julia H., \& White, David W. CERT ${ }^{\circledR}$ Resilience Management Model: A Maturity Model for Managing Operational Resilience. Addison-Wesley, 2011.

\section{[Caralli 2007]}

Caralli, Richard A., Stevens, James F., Young, Lisa R., \& Wilson, William R. Introducing OCTAVE Allegro: Improving the Information Security Risk Assessment Process (CMU/SEI-2007TR-012). Software Engineering Institute, Carnegie Mellon University, 2007. http://www.sei.cmu.edu/library/abstracts/reports/07tr012.cfm

\section{[Humphrey 1989]}

Humphrey, Watts. Managing the Software Process. Addison-Wesley, 1989.

\section{[SPC 1996]}

Software Productivity Consortium. Improving the Software Process through Process Definition and Modeling. International Thomson Computer Press, 1996.

\section{[Stevens 2005]}

Stevens, James F., Caralli, Richard A., \& Willke, Bradford J. Information Asset Profiling (CMU/SEI-2005-TN-021). Software Engineering Institute, Carnegie Mellon University, 2005. http://www.sei.cmu.edu/library/abstracts/reports/05tn021.cfm 
CMU/SEI-2011-TN-029 | 47 


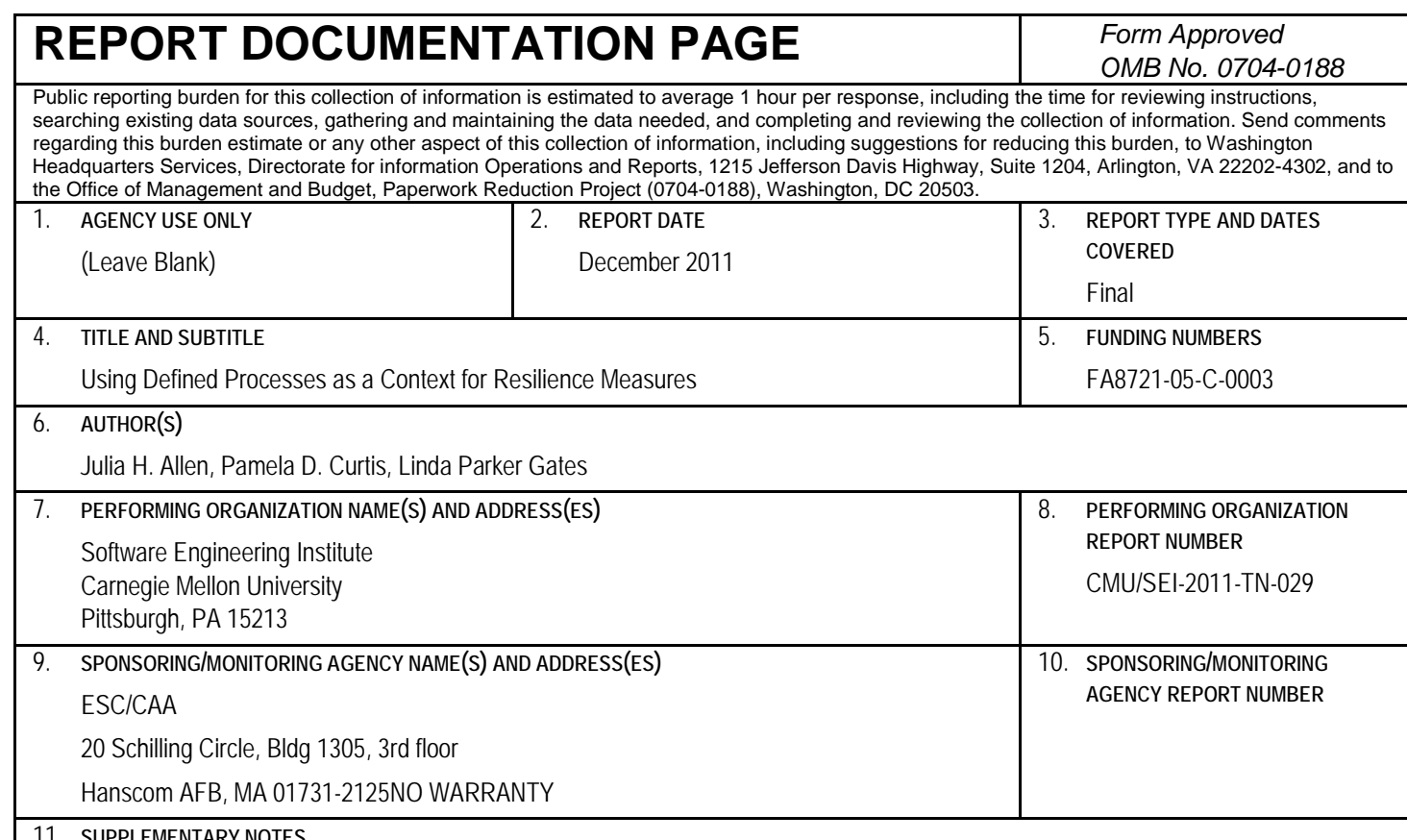

11. SUPPLEMENTARY NOTES

\begin{tabular}{l|l}
\hline $\begin{array}{l}\text { 12A DISTRIBUTION/AVAILABILITY STATEMENT } \\
\text { Unclassified/Unlimited, DTIC, NTIS }\end{array}$ & 12B DISTRIBUTION CODE \\
\hline 13. ABSTRACT(MAXIMUM 200 WORDS)
\end{tabular}

13. ABSTRACT (MAXIMUM 200 WORDS)

The CERT ${ }^{\oplus}$ Resilient Enterprise Management (REM) team is researching operational resilience and the organizational processes that support it. The team's first report, Measuring Operational Resilience Using the CERT ${ }^{\circledast}$ Resilience Management Model (CMU/SEI-2010TN-030), defined high-level objectives for managing an operational resilience management system, demonstrated how to derive meaningful measures from those objectives, and presented a template for defining resilience measures. The team's second report, Measures for Managing Operational Resilience (CMU/SEI-2011-TR-019), suggested strategic measures for managing operational resilience and provided candidate measures for the 26 process areas of the CERT ${ }^{\circledR}$ Resilience Management Model, Version 1.1 (CERT ${ }^{\circledR}$-RMM).

This technical note describes how implementation-level processes can provide the necessary context for identifying and defining measures of operational resilience. While CERT-RMM defines the commonly used or best practices for operational resilience-what an organization should do-organization-specific processes must be defined at the implementation level to describe how to perform those practices. Organizations can then identify and define measures within the context of their specific processes and constituent procedures. Organizations can use the measures to evaluate process performance and operational resilience and identify opportunities for improvement. This technical note provides examples and templates for defining processes and procedures and for defining related assets and measures.

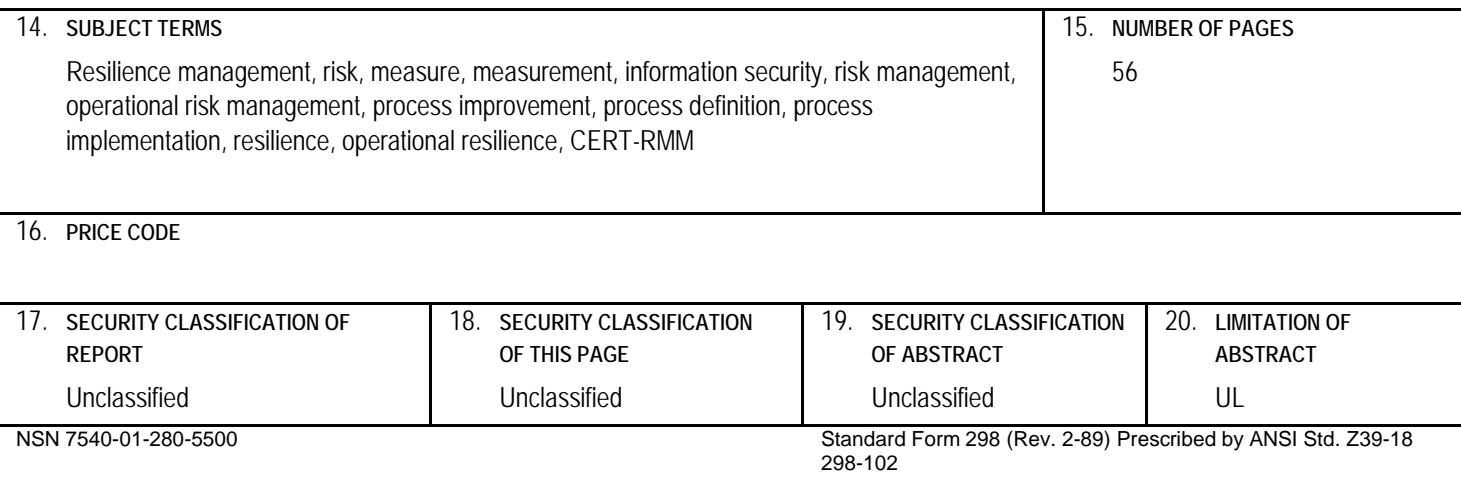

